\title{
Ship emissions and the use of current air cleaning technology: contributions to air pollution and acidification in the Baltic Sea
}

\author{
Björn Claremar, Karin Haglund, and Anna Rutgersson \\ Department of Earth Sciences, Uppsala University, 75236 Uppsala, Sweden \\ Correspondence to: Anna Rutgersson (anna.rutgersson@met.uu.se) \\ Received: 12 October 2016 - Discussion started: 25 October 2016 \\ Revised: 9 August 2017 - Accepted: 24 August 2017 - Published: 13 October 2017
}

\begin{abstract}
The shipping sector is a significant contributor to emissions of air pollutants in marine and coastal regions. In order to achieve sustainable shipping, primarily through new regulations and techniques, greater knowledge of dispersion and deposition of air pollutants is required. Regional model calculations of the dispersion and concentration of sulfur, nitrogen, and particulate matter, as well as deposition of oxidized sulfur and nitrogen from the international maritime sector in the Baltic Sea and the North Sea, have been made for the years 2011 to 2013. The contribution from shipping is highest along shipping lanes and near large ports for concentration and dry deposition. Sulfur is the most important pollutant coupled to shipping. The contribution of both $\mathrm{SO}_{2}$ concentration and dry deposition of sulfur represented up to $80 \%$ of the total in some regions. WHO guidelines for annual concentrations were not trespassed for any analysed pollutant, other than $\mathrm{PM}_{2.5}$ in the Netherlands, Belgium, and central Poland. However, due to the resolution of the numerical model, $50 \mathrm{~km} \times 50 \mathrm{~km}$, there may be higher concentrations locally close to intense shipping lanes. Wet deposition is more spread and less sensitive to model resolution. The contribution of wet deposition of sulfur and nitrogen from shipping was up to $30 \%$ of the total wet deposition. Comparison of simulated to measured concentration at two coastal stations close to shipping lanes showed some underestimations and missed maximums, probably due to resolution of the model and underestimated ship emissions.

A change in regulation for maximum sulfur content in maritime fuel, in 2015 from 1 to $0.1 \%$, decreases the atmospheric sulfur concentration and deposition significantly. However, due to costs related to refining, the cleaning of exhausts through scrubbers has become a possible economic solution. Open-loop scrubbers meet the air quality criteria but their consequences for the marine environment are largely unknown. The resulting potential of future acidification in the Baltic Sea, both from atmospheric deposition and from scrubber water along the shipping lanes, based on different assumptions about sulfur content in fuel, scrubber usage, and increased shipping density has been assessed. The increase in deposition for different shipping and scrubber scenarios differs for the basins in the Baltic Sea, with highest potential of acidification in the southern basins with high traffic. The proportion of ocean-acidifying sulfur from ships increases when taking scrubber water into account and the major reason for increasing acidifying nitrogen from ships is increasing ship traffic. Also, with the implementation of emission control for nitrogen, the effect of scrubbers on acidification is evident. This study also generates a database of shipping and scrubber scenarios for atmospheric deposition and scrubber exhaust from the period 2011 to 2050 .
\end{abstract}




\section{Introduction}

Emissions of air pollutants is a large problem; air pollutants have harmful effects on human health, the environment, and buildings. They also influence climate and water quality (Seinfeld and Pandis, 2006; Monks et al., 2009; Fuglestvedt and Berntsen, 2009). There has been a significant decrease in land-based emissions over land areas in Europe since the risks associated with high levels of air pollutants were brought to light 2 decades ago. During the same time, however, emissions from shipping in the Baltic Sea and the North Sea have increased, with the exception of a very recent decrease in sulfur emissions and successive emissions of particulate matter (PM) due to regulations (Gauss et al., 2013; Jonson et al., 2015). Shipping is the most cost-effective option for global transport of goods, and over $90 \%$ of world trade is carried by sea (IMO, 2016). The Baltic Sea area is one of the busiest shipping areas in the world and it is of great importance for the development and economy of the surrounding countries. The intensity of shipping in the Baltic Sea has increased during the last decade and it is expected to increase further in the coming years.

Shipping primarily generates emissions of nitrogen oxides $\left(\mathrm{NO}_{x}\right)$, sulfur dioxide $\left(\mathrm{SO}_{2}\right)$, carbon monoxide $(\mathrm{CO})$, carbon dioxide $\left(\mathrm{CO}_{2}\right)$, volatile organic compounds, and PM (Corbett and Fischbeck, 1997; Eyring et al., 2010; Matthias et al., 2010). Maritime contribution of sulfur dioxide into the atmosphere is mainly caused by the high sulfur content in the fossil fuels used by the sector (Eyring et al., 2005). Nitrogen oxides include nitric oxide (NO) and nitrogen dioxide $\left(\mathrm{NO}_{2}\right)$, which are emitted from engines that operate under high temperature and pressure (Eyring et al., 2010). PM from shipping consists of a complex mixture of sulfate $\left(\mathrm{SO}_{4}\right)$, soot, metals, and other organic and inorganic fragments (Winnes et al., 2014), the prime component being sulfate, which is formed by oxidation of $\mathrm{SO}_{2}$ (Eyring et al., 2010). The quantity and size of PM emitted from shipping depends mainly on the type of fuel and its sulfur content, as well as the ship's engine (Fridell et al., 2008; Van Aardenne et al., 2013). PM is divided into $\mathrm{PM}_{10}$ and $\mathrm{PM}_{2.5}$ in terms of its aerodynamic diameter, where $\mathrm{PM}_{10}$ has an aerodynamic diameter less than $10 \mu \mathrm{m}$, while $\mathrm{PM}_{2.5}$ has a diameter less than $2.5 \mu \mathrm{m}$. $\mathrm{SO}_{2}$ is also chemically transformed into sulfuric acid in the presence of liquid water or water vapour and can cause acid rain, which contributes to the acidification of the oceans, lakes, and soil. Sulfur and nitrogen from oxides are called oxidized sulfur (OXS) and oxidized nitrogen (OXN) in deposition and both act as acidifying compounds.

Effects of air pollution vary in both space and time; they may be short-lived and local or more prolonged and global (Seinfeld and Pandis, 2006). Exposure to PM encompasses a variety of risks to human health, primarily on the respiratory organs and the cardiovascular system (World Health Organization, 2006). Corbett et al. (2007) estimated that shipping-related emissions of PM contribute to approxi- mately 60000 deaths annually on a global scale, with impacts concentrated to coastal areas along the major trade routes. Further, PM may be absorbing or reflecting, which has an impact on the Earth's radiation balance. The net effect of emissions from the maritime sector on the radiation balance is negative, resulting in a cooling effect (Eyring et al., 2005; Fuglestvedt and Berntsen, 2009). Jonson et al. (2015), hereafter abbreviated J15, estimated that current emissions from shipping in the Baltic Sea region cause a shortening of life expectancy by $0.1-0.2$ years per person in areas close to the main shipping lanes. Exposure to high levels of sulfur oxides causes health issues such as irritation to the respiratory system, lungs, and eyes (World Health Organization, 2006). High levels of nitrogen in the atmosphere also have negative impacts on human health, cause corrosion of materials, and are included in the process of degradation of methane (Fuglestvedt and Berntsen, 2009; Eyring et al., 2010). Deposition of nitrate contributes to both eutrophication and acidification of water and soil. A pH reduction in the ocean causes worsening conditions in a lot of marine ecosystems (Andersson et al., 2008). Hunter et al. (2011) modelled acidification from strong acids in the North Sea, Baltic Sea, and South China Sea. On an annual scale the trends were on the order of $10^{-4} \mathrm{pH}$ units per year, comparable to the global assessment by Doney et al. (2007). Hassellöv et al. (2013) modelled $\mathrm{pH}$ decrease from shipping worldwide on the seasonal scale. Areas with heavy ship traffic and seasonal stratification of the surface water showed a larger $\mathrm{pH}$ decrease, comparable to the effects from $\mathrm{CO}_{2}$ uptake. Thus, locally the annual decrease is of the order of $0.002 \mathrm{pH}$ units (Orr, 2011; Rhein et al., 2013). On the annual scale the results from Hassellöv et al. (2013) are comparable with Hunter et al. (2011) and Doney et al. (2007). Acidification is a major challenge in the Baltic Sea region today where the critical load is exceeded in big parts of the area (Gauss et al., 2013). Due to its brackish water, the Baltic Sea has a rather lower buffer capacity and is thus more sensitive to acidification (Andersen et al., 2010).

The maritime sector was, at least earlier, one of the least controlled sources of anthropogenic emissions. It is a global cross-border sector with conditions making legislation challenging (Van Aardenne et al., 2013). The International Maritime Organization (IMO) is the agency within the United Nations (UN) responsible for maritime security and safety together with prevention of pollutants by ships (IMO, 2016). IMO has formulated the International Convention for the Prevention of Pollution from Ships (MARPOL), which has been ratified globally (CleanShip, 2013). MARPOL and its Annex VI regulate emissions from ships.

The regulations include the Sulphur Emission Control Area (SECA), which consists of the Baltic Sea, North Sea, English Channel, and North America's coastal areas (IMO, 2017; J15). Residual oil or high-sulfur fuel oil (HSFO) can have up to $3.5 \%$ sulfur content, but a global mean estimate is $2.4 \%$ (IMO, 2009) to $2.7 \%$ outside SECA (ENTEC, 2005). In the SECAs a number of reductions have been made. In 
May 2006 the sulfur content in maritime fuel was restricted to $1.5 \%$ (percentage by mass) by refining to marine gas oil. In 2010 , it was reduced to $1.0 \%$ and according to $\mathrm{J} 15$, this reduction of sulfur had a positive effect on air quality and the deposition of sulfur. A further reduction of the permitted level of sulfur to $0.1 \%$ was made in January 2015 (Van Aardenne et al., 2013). From 1 January 2020 the upper sulfur content should be reduced to $0.5 \%$ globally (outside the SECAs), even if 2025 is more probable outside the European Union (Jonson et al., 2015). The reduction in SECA has led to extensive investment in scrubbers, or exhaust gas cleaning systems (EGCSs), since the increases in refined oil price. Scrubbers use seawater to remove the sulfur oxides generated from high-sulfur fuels. An expected effect of open-loop scrubbers is that acidification is concentrated along the shipping lanes as the scrubber exhaust is released into the water. With scrubbers the ships can still use HSFO and it seems that the $0.5 \%$ limit can be avoided (S\&P Global Platts, 2016).

There is currently no international regulation of direct particulate emissions from shipping. However, with less sulfur, particle emissions will also decrease, but since there are other sources as well, the decrease is less. The regulations of nitrogen emissions in MARPOL (TIER) are defined as a function of year of installation and ship speed (IMO, 2007). The TIER I standard was implemented in 2000 and was $10 \%$ stricter than for ships built before 2000. The introduction of TIER II in 2011 was up to $15 \%$ stricter then the former. As regulations only include newly produced ships, the effects of regulations of nitrogen emissions from shipping have so far been small. There are also Nitrogen Oxide Emission Control Areas (NECAs), e.g. in the Caribbean Sea and along the North American coast, but so far, not in the Baltic Sea and North Sea. However, at the end of 2016 it was decided that in 2021 a NECA will be introduced for the Baltic Sea and North Sea. There are indications that with this introduction, emissions of $\mathrm{NO}_{x}$ will decrease by $80 \%$ relative to the TIER I level (J15). In J15 it was assumed that half of the fleet will follow the TIER III commitment by 2030, and all ships will follow the commitment in 30 years (2050). In addition to HSFO and low-sulfur oil, there are also other possible fuels, like liquefied natural gas and methanol.

J15 did a thorough study of air pollutants from shipping in the Baltic Sea and the North Sea. They used the European Monitoring and Evaluation Programme (EMEP) model (Simpson et al., 2012) and estimated the effects of present and future emissions of $\mathrm{NO}_{2}, \mathrm{SO}_{2}$, and particles as $\mathrm{PM}_{10}$ and $\mathrm{PM}_{2.5}$, among other compounds. As ship emission data they used the Ship Traffic Emission Assessment Model (STEAM) (Jalkanen et al., 2009, 2012). This model is based on movements of individual ships with high temporal resolution (automatic identification system, AIS) together with engine times and corresponding emission factors. The concentrations and depositions were analysed for the year 2010. Concentrations were focused along the shipping routes but there was a significant spread for depositions. The effect of the reduced sulfur content in the fuel implemented in 2010 and the effect of future scenarios with reduced sulfur content ( 2015 value of $0.1 \%$ ) and regulation of NECAs was also investigated.

The present study is to some extent similar to $\mathrm{J} 15$; we study deposition and near-surface concentrations originating from shipping, also introducing the estimation of the future effects from scrubbers in the Baltic Sea. We use the same chemical transport model as J15, the EMEP model, although at a lower resolution, $50 \mathrm{~km} \times 50 \mathrm{~km}$, compared to $14 \mathrm{~km} \times 14 \mathrm{~km}$. There are some differences compared to J15, we use default ship emission data for the EMEP model, whereas J15 use AIS-based ship emissions. We analyse the present concentration due to ship emissions and its deposition but focus on the sulfur exhausts in a future scenario, relying on scrubber technique (defining suggested scenarios for use of scrubbers). The model is run for 5 years (2009 to 2013) and by using scenarios for future shipping and cleaning technologies, estimates of deposition (from air and scrubber) into the Baltic Sea until 2050 are derived. The use and averaging of 3 years (2009-2011) for the present deposition fields reduces the variability from meteorology for the future scenarios. The scenarios are limited to "worst-case scenarios" regarding the use of scrubbers, but the results will be discussed in relation to other possibilities. In the analysis of the period around 2010, we examine the impact of coarse resolution on concentration and deposition as well as using non-AIS databases for ship emissions, when comparing our results to $\mathrm{J} 15$. Concentrations may, for instance, be very dependent on resolution, whereas deposition may be less sensitive.

\section{Data}

\subsection{EMEP model system}

The unified EMEP is policy driven under the Convention on Long-range Transboundary Air Pollution (CLRTAP) for international co-operation to solve transboundary air pollution problems. The programme is divided into five centres working with emission inventories, measurements, and chemical and dispersion modelling (http://www.emep.int/). The EMEP model is a chemical atmospheric transport model (http://emep.int/mscw/index_mscw.html). The model is Eulerian and traditionally consists of a three-dimensional grid that covers Europe. The standard horizontal resolution is approximately $50 \mathrm{~km} \times 50 \mathrm{~km}$ at $60^{\circ} \mathrm{N}$ and has 20 layers in the vertical direction up to $100 \mathrm{hPa}$. Land use is separated into 16 classes. Emissions included in the EMEP model are sulfur dioxide, nitrogen oxides, ammonia $\left(\mathrm{NH}_{3}\right)$, non-methane volatile organic compounds, carbon monoxide, and PM. The model's lateral boundary concentrations consist of a merging of observed data and results from global models. A more comprehensive description of the EMEP model can be found in Simpson et al. (2012). 
The EMEP model is considered to be a robust model for dispersion modelling in the atmosphere (Simpson et al., 2012; Gauss et al., 2015). In Gauss et al. (2015), a comparison of model results from the EMEP model version rv.4.7 and observations of annual averages of concentrations at individual stations for 2013 was made. On average, sulfur dioxide concentration was underestimated by $11 \%$, nitrogen dioxide was underestimated by $7 \%, \mathrm{PM}_{10}$ was underestimated by $28 \%$, and $\mathrm{PM}_{2.5}$ was underestimated by $19 \%$. Validation of wet and dry deposition of OXN and OXS based on approximately 30 test sites in 2013 shows, despite the limitations of the model, a relatively good agreement with observed data, considering a low bias and good correlation (Gauss et al., 2015).

\subsection{EMEP model data}

The meteorological input data used in the EMEP model are from the Integrated Forecast System (IFS), which is a global forecast model run by the European Centre for MediumRange Weather Forecasts (ECMWF). Chemical data used in the EMEP model cover 56 persistent and 15 short-lived components, chemical reactions, phase changes, and solubility in water. Emission inputs consist of gridded yearly national emission data (Vestreng, 2003; Simpson et al., 2012). The anthropogenic emissions are categorized into 10 different groups called Selected Nomenclature for Sources of Air Pollution (SNAP). All nations in the EMEP area are responsible for reporting annual gridded emission data for each SNAP sector. National shipping is included in SNAP 8 (other mobile sources and machinery) and is a part of the emission data that each nation should report. International shipping is also included in SNAP 8. International ship emission data used in the model were designed according to Table 1. In EMEP model rv.4.4, ship emissions and their distributions were mainly from the ENTEC/(IIASA) International Institute for Applied Systems Analysis inventory. ENTEC UK Ltd. (now part of AMEC Environment Infrastructure, UK, www.amec-ukenvironment.com) compiled an emission inventory for 2000 (ENTEC, 2002) based on Lloyd's Register (1998). In addition, data on ship activity in ports were acquired using questionnaires (ENTEC, 2002). IIASA has updated these data in recent years with trends (Cofala et al., 2007).

In the development of the data set in EMEP model version rv.4.8, new aspects, such as SECA, the economic situation, and the use of different sizes of ships, have been included. The emission data were designed for 2000 to 2011. In order to supplement emission data for the following years, extrapolation with the Centre on Emission Inventories and Projections (CEIP) method were used. This interpolation was, however, shown to significantly underestimate the 2012 and 2013 emissions in the North Sea and in the Baltic Sea (Fagerli et al., 2015). Emissions from international shipping are assumed to be constant throughout the day and year in the
Table 1. International ship emission data for the different versions of the EMEP model used in this study.

\begin{tabular}{lll}
\hline $\begin{array}{l}\text { EMEP } \\
\text { model } \\
\text { version }\end{array}$ & $\begin{array}{l}\text { Simulated } \\
\text { years }\end{array}$ & International ship emission data \\
\hline rv.4.4 & $2009-2011$ & $\begin{array}{l}\text { ENTEC international shipping data } \\
\text { (Jonson et al., 2009; ENTEC, 2010) } \\
\text { and trends after 2000 are from IIASA }\end{array}$ \\
(Cofala et al., 2007) \\
rv.4.8 $2011-2013$ & $\begin{array}{l}\text { Based on data from TNO-MACC-III } \\
\text { (Gauss et al., 2015) in the EU Hori- } \\
\text { zon 2020 project MACC III (Gauss } \\
\text { et al., 2015) }\end{array}$ \\
\hline
\end{tabular}

model (Simpson et al., 2012). This was also shown by Jalkanen et al. (2014), with emissions being within $10 \%$ in the years 2006-2009.

Between model versions several changes that affect aerosol production and modelling have been implemented by the EMEP community, e.g. modification of the sea salt parametrization, changes in the standard aerosol surface area and uptake rates, dust boundary conditions, and an update of the split of PM into elemental carbon, organic matter, and the remainder. Furthermore, biogenic emissions of dimethyl sulfide (DMS) have been updated. Rather than being prescribed, DMS emissions are now calculated dynamically during the model calculation and vary with meteorological conditions.

Comparing the emissions in EMEP rv.4.4 and 4.8 shows very small differences, on the order of less than $1 \%$. However, deposition and concentrations deviate significantly due to the new modifications of the chemistry and physics. Figure 1 shows the relative change in 2011 (\%) going from rv.4.4 to 4.8 in deposition (from shipping) of OXS and OXN, respectively. Overall, the deposition has increased but mostly over land, and OXN has increased in the northern Atlantic and OXS has increased north of Great Britain. In the Baltic Sea the increase is minor for OXS, less than $10 \%$, but for OXN the increase is between 5 and $30 \%$.

\subsection{Other data sources}

Historical ship emission data were taken from the global gridded EDGAR 4.2 data set (Olivier et al., 2011), with a horizontal resolution of $0.1^{\circ}$, available from 1970 to 2008 (http://edgar.jrc.ec.europa.eu). For the 1900-1969 period, the EDGAR-HYDE 1.3 data set has a resolution of $1^{\circ}$ (Van Aardenne et al., 2001). Both these data sets contain global anthropogenic emissions of $\mathrm{NO}_{x}, \mathrm{SO}_{2}, \mathrm{NH}_{3}$, and other species. The EDGAR-HYDE data are derived from historical activity data from the 10-year-interval Hundred Year Database for Integrated Environmental Assessments (HYDE), 18901990. These data are based on the data and methodology of EDGAR 2.0 (Olivier et al., 1996). Linear interpolation of the 
(a) $\triangle \mathrm{OXS}$

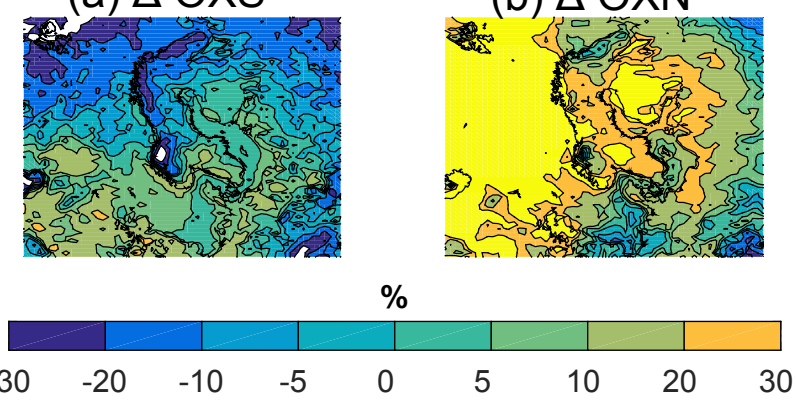

Figure 1. Difference (\%) in deposition due to shipping, from EMEP model rv.4.4 to rv.4.8 run for the year 2011 for (a) oxidized sulfur and (b) oxidized nitrogen.

emissions was used to fill the gaps between the 10-year intervals of EDGAR-HYDE 1.3.

For background emissions of $\mathrm{SO}_{2}, \mathrm{NO}_{x}$, and the deposition of OXS, OXN (i.e. from sources other than ship traffic) output from the MATCH chemical transport model (Robertson et al., 1999) was used. We used a simulation for the 1900-2050 period set up as described by Engardt and Langner (2013). Forcing was based on the RCP 4.5 radiative scenario and accompanying anthropogenic emissions (Lamarque et al., 2010). Shipping emissions were from Eyring et al. (2010), and the International Comprehensive Ocean-Atmosphere Data Set (ICOADS) spatial proxies were used.

\subsection{Measurements}

We validated the EMEP modelled data for 2013 using measured concentrations of nitrogen dioxide, sulfur dioxide, and PM from stations Vavihill and Utö (Fig. 2). Data for Vavihill were downloaded from the database of the Swedish Environmental Research Institute (http://www.ivl.se/sidor/omraden/ miljodata/luftkvalitet.html) and data for Utö were from the Finnish Meteorological Institute's website (http://www. ilmanlaatu.fi/tarkistetut_tulokset/). The measuring station in Vavihill is located in the Svalöv municipality $\left(56.142^{\circ} \mathrm{N}\right.$, $\left.13.855^{\circ} \mathrm{E}\right), 28 \mathrm{~km}$ from the port city of Helsingborg and $25 \mathrm{~km}$ from the coast of Øresund (Fig. 2). Within a radius of $10 \mathrm{~km}$ from the measuring station, no emission sources that are assumed to have a significant impact on air quality are present. At the distance of $10 \mathrm{~km}$ from the measuring station, there is a road that experiences heavy traffic and within $50 \mathrm{~km}$ the larger cities of Lund and Malmö are located (Sjöberg and Peterson, 2014; IVL Swedish Environmental Research Institute, 2015). The measuring station on Utö is located in the central part of the island $\left(59.779^{\circ} \mathrm{N}, 21.394^{\circ} \mathrm{E}\right)$, a few hundred metres from the shore (Fig. 2). About $300 \mathrm{~m}$ away from the test site, there is a smaller shipping lane and a harbour for small boats. About $10 \mathrm{~km}$ west of the measurement site, there

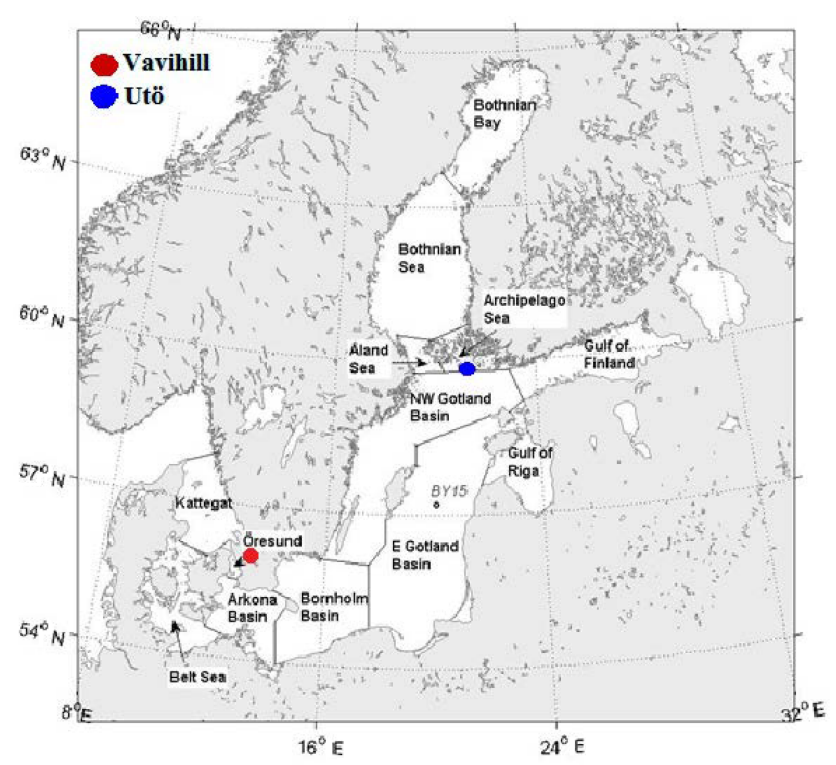

Figure 2. The division of the basins of the Baltic Sea-Skagerrak system. OR: Øresund; GO: Eastern Gotland Basin; AL: Åland Sea; BE: Belt Sea; NW: Northwest Gotland Basin; AS: Archipelago Sea; AR: Arkona Basin; GR: Gulf of Riga; BS: Bothnian Sea; KA: Kattegat; BH: Bornholm Basin; GF: Gulf of Finland; and BB: Bothnian Bay. Dots represent the measuring stations at Vavihill and Utö. The figure is redrawn from Omstedt et al. (2015).

is an international shipping lane that is heavily trafficked by larger vessels (Finnish Meteorological Institute, 2015).

\section{Methods}

\subsection{EMEP model runs}

This investigation consists of two parts. A database with historical and future scenarios of emissions and depositions of OXS and OXN (the database) was created. The EMEP model version rv.4.4 was used with meteorology from the years 2009 to 2011 and emissions from 2011 (see Sect. 3.3). In the second part, the model was validated to coastal measurements of concentrations for the year 2013 using the newer model version rv.4.8. As seen in Sect. 2.2, rv.4.8 gives higher depositions of OXS and especially OXN. This is further discussed in Sect. 5. Also, the spatial pattern of concentration and deposition was analysed and compared to the results from J15. For each studied year, two model runs in the EMEP model were made, a base run and a scenario run. In the base run, all emission sources were included, and in the scenario run, the emissions from international shipping in the Baltic Sea and North Sea were excluded (SNAP 8). The scenario run was subtracted from the base run to obtain the impact of the international maritime sector in the Baltic Sea and the North Sea. 


\subsection{Model performance of concentrations}

PM is difficult to measure and various measuring instruments register different types of particles, which result in some uncertainties to input data. Also, some semi-volatile compounds exist in both gaseous and particle form and the definition of the different particle groups vary in different countries. Moreover, there are still components of the coarser particles, such as aerosol and biogenic organic farming dust that are not included in EMEP model. Another uncertainty of the input data is that not all nations included in the EMEP area report yearly emissions (Gauss et al., 2015). We validated the EMEP modelled data for 2013 using measured concentrations of nitrogen dioxide, sulfur dioxide, and PM from the Vavihill and Utö stations.

Measured data were compared to daily averages of modelled data from the $50 \mathrm{~km} \times 50 \mathrm{~km}$ grid box where the measurement sites were localized. If measured data were specified in hourly values, calculations of daily averages were made. When measured data were missing for 1 day, the validation for this day was excluded in the evaluation. The evaluation included calculations of daily average, bias, correlation, RMSE, and also the $P$ test and scatter plots of model results vs. measured data of the daily average concentrations of sulfur dioxide, nitrogen dioxide, and PM.

\subsection{Future ship emissions}

Five future scenarios differing with respect to the sulfur content of the fuel and scrubber usage of the shipping fleet were developed (Table 2). Scenario no. 1 corresponds to the fuel content regulation from January 2010 to December 2014 ( $1 \%$ sulfur in the fuel), and scenario no. 3 (0.1\% sulfur in the fuel) corresponds to the regulations from January 2015. Scenario no. 2 has been included since in Sweden it was suggested as an alternative, low-cost reduction in sulfur content ( $0.5 \%$ sulfur in the fuel). In scenarios 4 and 5 , use of the open-loop wet scrubber technique for removing sulfur from the exhaust is assumed for 50 and $100 \%$ of the fleet, respectively. The use of scrubbers is assumed to increase linearly from no scrubber installations at all. The increase rate of the proportion of ships using scrubbers is the same for scenarios 4 and 5 but ends at 50 or $100 \%$, respectively. Hence, these are similar until 2020. It is assumed that the fuel used in the ships with scrubbers will have an average low-cost sulfur content of $2.7 \%$, corresponding to the current average outside the SECA (ENTEC, 2005). Further, it is assumed that the ships in the basins north of the Baltic, Archipelago, Aland, and Bothnian seas and Bothnian Bay cannot use the scrubber technique to a large extent. This is due to the ice properties in the winter and the low alkalinity. For scenarios 4 and 5 the emissions to the atmosphere are estimated to correspond to $0.1 \%$ sulfur in the fuel (following the regulations). To achieve atmospheric emissions corresponding to $0.1 \%$ sulfur in the fuel, it is assumed that $96 \%$ of the sulfur is taken up in
Table 2. Future scenarios that differ with respect to the sulfur content of the fuel and scrubber usage.

\begin{tabular}{|c|c|c|c|c|}
\hline \multirow{2}{*}{$\begin{array}{l}\text { Scenario } \\
\text { no. }\end{array}$} & \multicolumn{2}{|c|}{$\begin{array}{l}\text { Shipping not using wet } \\
\text { scrubbers }\end{array}$} & \multicolumn{2}{|c|}{$\begin{array}{l}\text { Shipping using wet } \\
\text { scrubbers }\end{array}$} \\
\hline & $\%$ of total & $\begin{array}{l}\% \text { sulfur } \\
\text { in fuel }\end{array}$ & $\%$ of total & $\begin{array}{c}\% \text { sulfur } \\
\text { in fuel }\end{array}$ \\
\hline 1 & 100 & 1.0 & 0 & \\
\hline 2 & 100 & 0.5 & 0 & \\
\hline 3 & 100 & 0.1 & 0 & \\
\hline 4 & 50 by 2020 & 0.1 & 50 by 2020 & 2.7 \\
\hline 5 & 0 by 2025 & 0.1 & 100 by 2025 & 2.7 \\
\hline
\end{tabular}

the scrubber, the scrubber water is untreated and discharged, and the sulfur oxides are directly transformed into strong sulfuric acid. Regulations of nitrogen oxide emissions are in an early stage. Therefore, these emissions are assumed to increase at the same rate as the shipping traffic. We here follow the TREMOVE European transport model (De Ceuster et al., 2006), which gives an increase of 2.5 and $3.9 \%$ per year for cargo and passenger traffic, respectively. In addition, the effect of a NECA was studied, following assumptions made in $\mathrm{J} 15$. There is no seasonal variation in ship emissions in the ENTEC/IIASA inventory (2011) and the monthly variation through the years 2006-2009 presented by Jalkanen et al. (2014) is rather low $( \pm 10 \%)$. Therefore, no seasonal variation in the future emissions is assumed.

\subsection{Deposition scenarios of ship emissions}

In Omstedt et al. (2015) a database for ship emissions and the corresponding depositions was constructed for the 19002011 period using a combination of emission databases (ENTEC/IIASA, EDGAR 4.2, and EDGAR-HYDE 1.3) and deposition from the EMEP model. For the years 2006-2009, the emission distribution was scaled to correspond to that presented by Jalkanen et al. (2014); for 2010, linear interpolation was used. Ship traffic was also assumed to follow the regulated changes in fuel sulfur content in the SECA area. We assume $2.7 \%$ sulfur in the fuel until May 2006, $1.5 \%$ until the end of 2009, and $1 \%$ thereafter. This information was also used to correct the EDGAR 4.2 emission fields. Further back in time, the emission fields from 1900 to 1970 from EDGAR-HYDE 1.3 were used.

Here we extend the database into the future using the alternative scenarios described in Sect. 3.3. We also use a similar methodology as in Omstedt et al. (2015), with the reference year 2011. The spatial distribution of atmospheric deposition of sulfur oxides and nitrogen oxides from ship traffic was estimated by the EMEP model. The model was first run for the meteorological years 2009 to 2011 with emissions from 2011. The variation in deposition between the three years indicated that the inter-annual effect of meteorology was low for annual deposition. Initial analysis to help find the better 

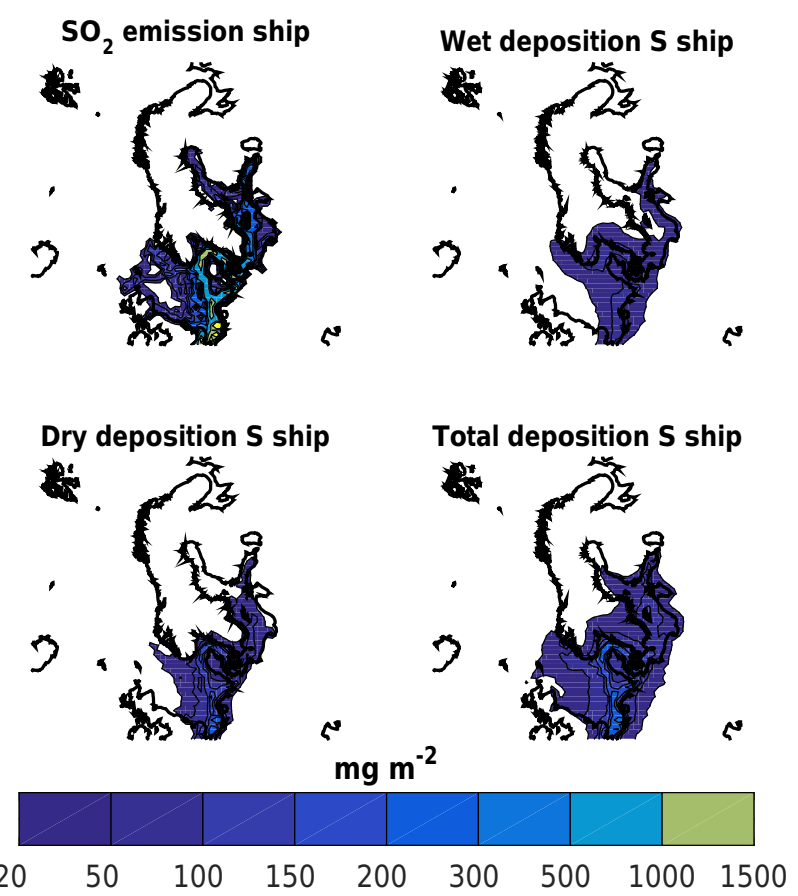

Figure 3. Total emissions of $\mathrm{SO}_{x}$ and deposition of OXS from international shipping in the Baltic Sea and North Sea in 2011.

method revealed that dry deposition is more focused along ship routes than wet deposition; the dry part of the deposition was thus assumed to be scaled by the local emissions. The wet deposition was more spread. Local ship emissions accounted for approximately $25 \%$ of deposition in the central Baltic Sea and approximately $45 \%$ of wet deposition in the Kattegat. In the Kattegat, almost half of the wet deposition originated from North Sea ship traffic, whereas a very small proportion of the wet deposition in the Baltic Sea east of Bornholm originated from the North Sea. Therefore, the wet deposition trends of sulfur oxides and nitrogen oxides in each basin were set equal to the local emission, except for the Kattegat, Belt Sea, and Øresund, where $50 \%$, as a first-order approximation, was assumed to depend on emission trends in the North Sea. This approach resulted in a reference year (2011) of deposition-to-emission ratios with a monthly resolution. The relative seasonal variability was kept throughout the period.

Non-ship emission trends follow the RCP 4.5 scenarios from 2010 (Lamarque et al., 2010) and deposition simulations (Engardt and Langner, 2013) using the MATCH model (Robertson et al., 1999). Ship emissions from RCP 4.5 (Eyring et al., 2010), including the traffic distribution from ICOADS (Wang et al., 2008), were replaced by our scenarios described in Table 2 . Total emissions were calculated by correspondingly correcting the MATCH output. Last, the spatial fields were averaged into the Baltic Sea basins defined in Fig. 2.

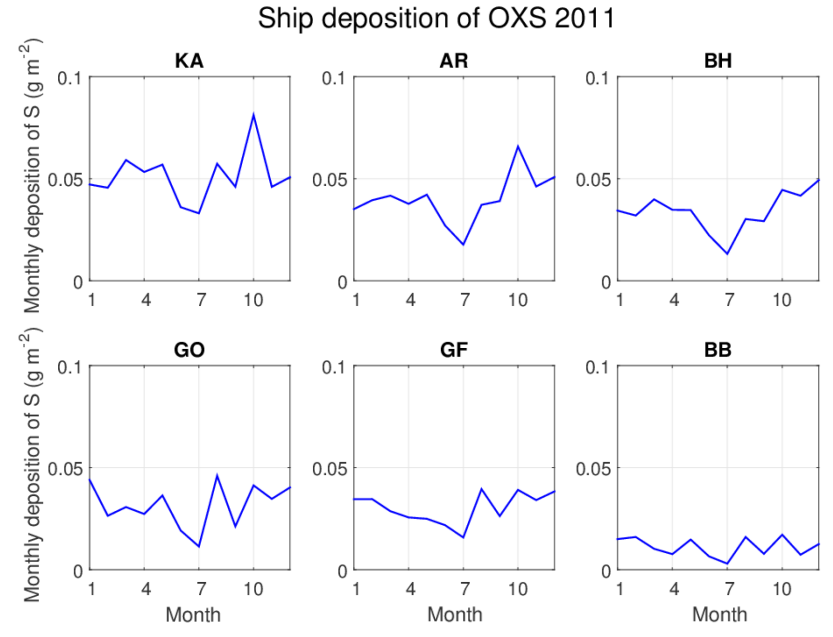

Figure 4. Monthly deposition of oxidized sulfur (OXS) in six basins of the Baltic Sea (defined in Fig. 2).

\section{Results}

\subsection{Ship deposition scenarios}

For the deposition scenarios, 2011 is the base year. That means that the relative spatial distribution of ship effects remains the same during the scenarios. Figure 3 shows the ship emissions and spatial distribution of dry, wet, and total deposition in 2011. Even if the ship emissions remain constant throughout the year, the weather causes the deposition pattern to change. In Fig. 4 the seasonal variations (mean of the meteorological years 2009-2011 and emissions from 2011) in the deposition of OXS are shown in six Baltic Sea basins (Kattegat, Arkona, Bornholm, Eastern Gotland, Gulf of Finland, and Bothnian Bay). In most basins there is a minimum during the summer and a maximum in the autumn.

The ship emission scenarios in the Baltic Sea are shown in Fig. 5. Emissions into the atmosphere (Fig. 5a) all show positive trends after 2015, due to the increasing traffic. With the traffic scenarios, emissions have more than doubled in 2050 compared to 2015. The reduction of sulfur content in fuel will, as expected, result in a reduction in sulfur emissions into the atmosphere in the Baltic Sea area. With scrubbers, the OXS goes directly into the water along the shipping lines. Note that it is assumed that ships are not using scrubbers north of the Baltic Sea proper (as discussed in Sect. 3.3). Averaged over the whole complete Baltic Sea (Fig. 5b), it is seen that, if using $2.7 \%$ sulfur fuel, the input of OXS into the sea surpasses the deposition from the $1 \%$ scenario already by 2020. This is regardless of which scenario ( 4 or 5 ) is used. If all ships in the region south of Åland use scrubbers and fuel with a sulfur content of $2.7 \%$, the emission of sulfur oxides into the Baltic Sea is expected to be almost 3 times the size in 2050, compared to if no scrubbers and fuel with a sulfur content of $1.0 \%$ were used (Fig. 5b). 
Table 3. Total deposition of OXS and OXN in the Baltic Sea $\left(\mathrm{Gg} \mathrm{yr}^{-1}\right)$.

\begin{tabular}{|c|c|c|c|c|}
\hline & \multicolumn{2}{|c|}{ OXS } & \multicolumn{2}{|c|}{ OXN } \\
\hline & $\begin{array}{r}\text { w/o } \\
\text { scrubber } \\
\text { (scen. 3) }\end{array}$ & $\begin{array}{r}\text { w/ } \\
\text { scrubber } \\
\text { (scen. 4) }\end{array}$ & $\begin{array}{c}\text { w/o } \\
\text { NECA }\end{array}$ & $\begin{array}{c}\text { w/ } \\
\text { NECA }\end{array}$ \\
\hline Tot dep. 2011 & 160 & 160 & 77 & 77 \\
\hline Tot dep. 2030 & 94 & 183 & 71 & 52 \\
\hline Tot dep. 2050 & 95 & 227 & 88 & 37 \\
\hline From ships $2011(\%)$ & 18 & 18 & 35 & 35 \\
\hline From ships $2030(\%)$ & 5 & 51 & 60 & 45 \\
\hline From ships $2050(\%)$ & 7 & 61 & 72 & 34 \\
\hline
\end{tabular}
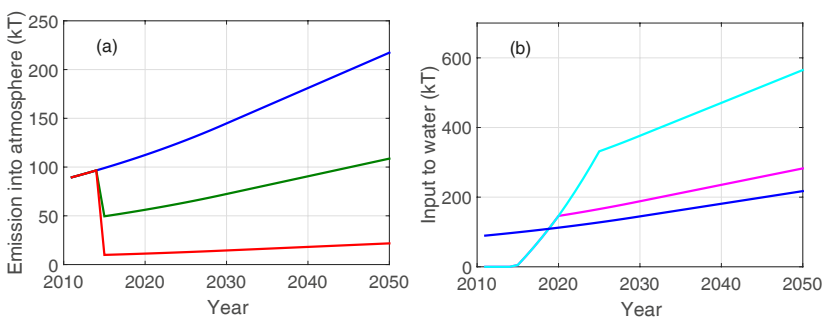

Figure 5. (a) Emissions of oxidized sulfur into the atmosphere in the Baltic Sea area (kt) from 2010 to 2050 for scenarios 1 to 3 . The blue line corresponds with scenario 1, the green line with scenario 2, and the red line with scenario 3. (b) Emission directly into the water of the Baltic Sea (kt) for scenarios 1, 4, and 5 in 2010 to 2050. The magenta line corresponds with scenario 4 and the cyan line with scenario 5. For comparison, the blue line shows the atmospheric deposition from scenario 1.

The deposition scenarios of sulfur from shipping, together with the historical data from Omstedt et al. (2015), are shown in Fig. 6. The deposition of sulfur from ship emissions in the Baltic Sea increased rapidly until the 1970s and then more slowly until 2005 (e.g. Claremar et al., 2013). When applying scenario 2 or 3 the deposition becomes significantly lower. The total deposition of sulfur in the Baltic Sea, from all emission sources, reached its maximum in the second part of the 1900s. It has decreased steadily since then and the deposition of sulfur is expected to continue to be low for the examined time period from present to 2050 (Fig. 7). The contribution of deposition of OXS from shipping is expected to increase somewhat from 2010 to 2050 in all basins of the Baltic Sea, but the levels will stay low. The deposition of sulfur from all emission sources is predicted to be rather invariable from 2010 to 2050, as given from RCP4.5.

The deposition in the whole Baltic Sea is presented in Table 3. The ship contribution to the total atmospheric OXS deposition will decrease, from $18 \%$ in 2011 to $5 \%$ in 2030, and $7 \%$ in 2050 (scenario 4). With scrubbers, the contribution adds up to more than $50 \%$. In 2050 the atmospheric deposition will have been reduced from 160 to $95 \mathrm{Gg} \mathrm{yr}^{-1}$, but
Ship deposition of S
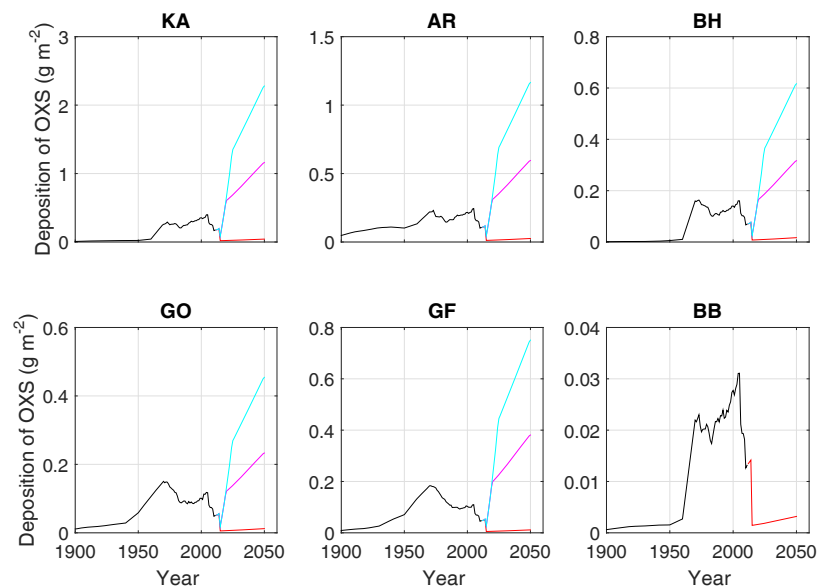

Figure 6. Annual ship deposition of sulfur $\left(\mathrm{mg} \mathrm{m}^{-2}\right)$ in six basins of the Baltic Sea (defined in Fig. 2), for the years 1900 to 2050. The red line corresponds with shipping scenario 3 and the magenta and cyan lines correspond with shipping scenarios 4 and 5, respectively (scrubber + atmospheric deposition). The black line shows historical shipping (derived in Omstedt et al., 2015). It is assumed here that scrubbers are not used in the Bothnian Bay.

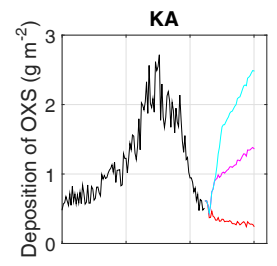

\section{Deposition of S}
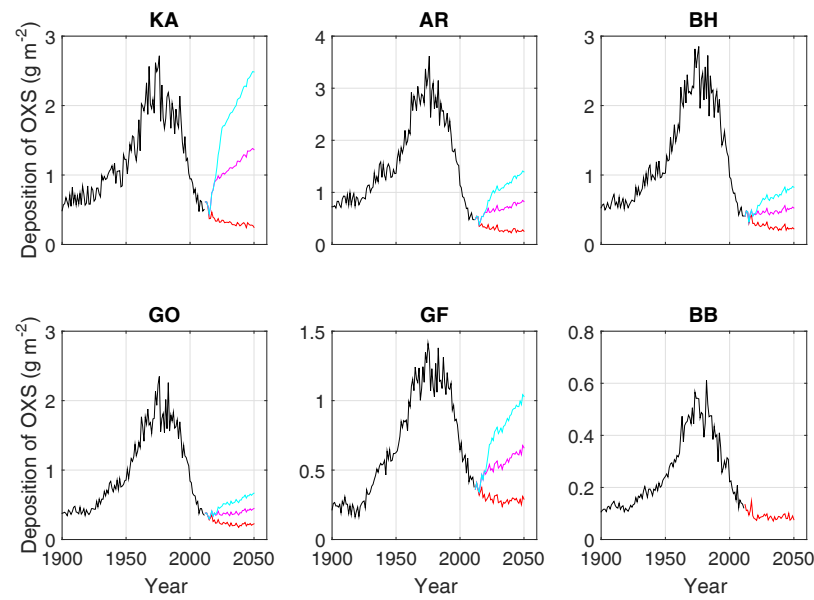

Figure 7. Annual deposition of sulfur from all emission sources $\left(\mathrm{g} \mathrm{m}^{-2}\right)$ in six basins of the Baltic Sea (defined in Fig. 2), for the years 1900 to 2050 . The red line corresponds with shipping scenario 3 and the magenta and cyan lines correspond with shipping scenarios 4 and 5, respectively (scrubber + atmospheric deposition). The black line shows historical shipping (derived in Omstedt et al., 2015).

with scrubbers the input into the Baltic Sea will increase to $227 \mathrm{Gg} \mathrm{yr}^{-1}$, an increase of $42 \%$ (scenario 4).

The deposition of nitrogen from ship emissions is expected to increase in all the basins in the Baltic Sea from present to 2050 as we do not include any coming regulations on nitrogen (Fig. 8). The increase is due to an increase in traffic sce- 


\section{Ship deposition of $\mathrm{N}$}
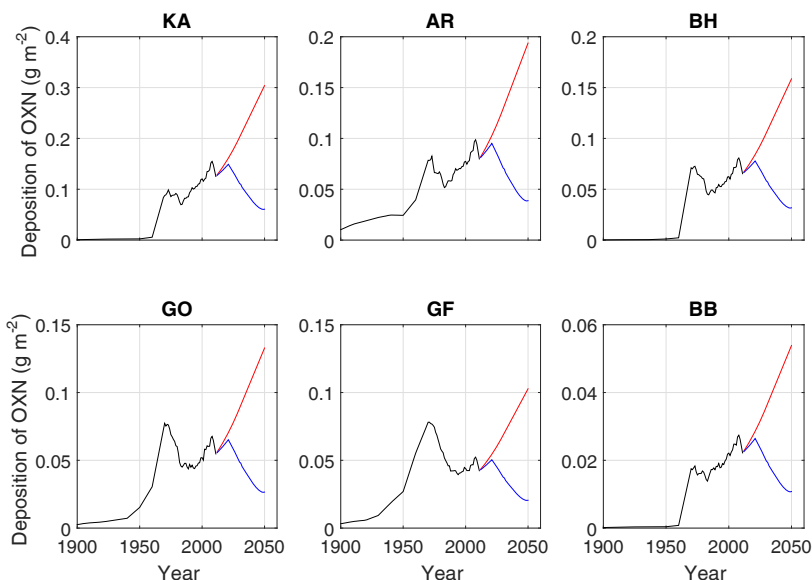

Figure 8. Annual ship deposition of nitrogen $\left(\mathrm{g} \mathrm{m}^{-2}\right)$ in six basins of the Baltic Sea (defined in Fig. 2), for the years 1900 to 2050. The red line corresponds with shipping scenarios 1 to 3 and the black line corresponds with historical shipping (derived in Omstedt et al., 2015). The blue line includes the implementation of TIER II and a NECA.

nario. The total deposition of nitrogen in the Baltic Sea, from all emission sources, is expected to increase in the Baltic Sea compared to the current deposition level (Fig. 9). The increase in nitrogen deposition varies significantly for the different basins, and for the Kattegat basin the highest values of nitrogen deposition in the 1970 s will be exceeded before the year 2050. The contribution of deposition of OXN from shipping is expected to become a more significant contributor to total deposition of OXN from 2010 to 2050 in all basins of the Baltic Sea (Table 3). The OXN deposition is significantly lower than in J15. They used the EC4MACS Interim Assessment (Amann et al., 2011), which indicates that the RCP 4.5 has a lower scenario for nitrogen. This means that if using EC4MACS data, the OXN deposition from shipping would be smaller, but the total effect would be larger.

The deposition for OXN in the whole Baltic Sea is presented in Table 3. The ship contribution to total increases for the atmospheric deposition, from $35 \%$ in 2011 to $60 \%$ in 2030 and $72 \%$ in 2050. In 2050 the atmospheric deposition has been increased from 77 to $88 \mathrm{Gg} \mathrm{yr}^{-1}$, not accounting for a NECA.

We have, so far, not accounted for the long-term shift to TIER II and TIER III in the NECA. The decision to create a NECA in the Baltic Sea and North Sea was made while preparing this paper. TIER II was introduced in 2011 and TIER III will be introduced in 2021. In Table 4, estimates from $\mathrm{J} 15$ are shown and a reduction of emissions of $26 \%$ in the Baltic Sea and $29 \%$ in the North Sea can be concluded in 2030, relative to emissions without a NECA, i.e. to ships mainly following TIER II. We apply a reducing factor to our deposition due to both TIER II implementation and the estab-

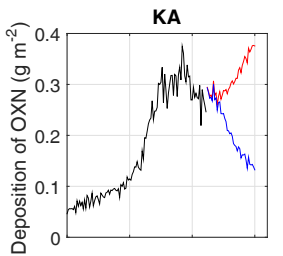

\section{Deposition of $\mathrm{N}$}
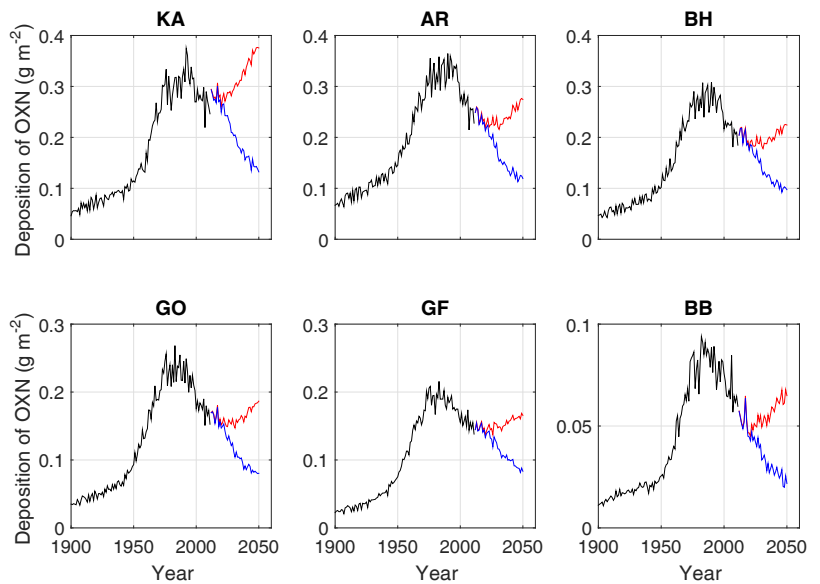

Figure 9. Annual deposition of nitrogen from all emission sources $\left(\mathrm{g} \mathrm{m}^{-2}\right)$ in six basins of the Baltic Sea (defined in Fig. 2), for the years 1900 to 2050 . The red line corresponds with shipping scenarios 1 to 3 and the black line shows historical shipping (derived in Omstedt et al., 2015).
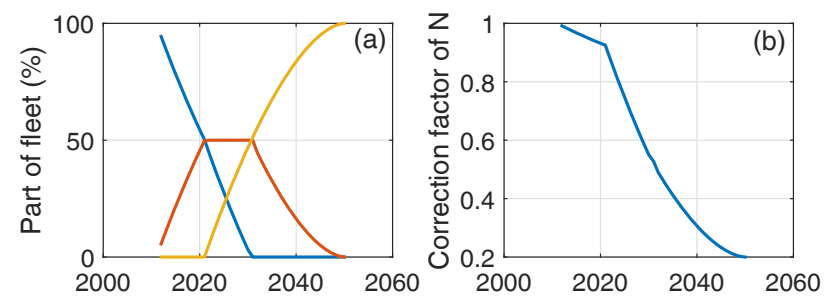

Figure 10. (a) Estimated part of fleet complying with TIER I (blue), TIER II (red), and TIER III/NECA (orange) restrictions. (b) Correction factor for OXN deposition from shipping, using the implementation of TIER II and TIER III in a NECA from 2021.

lishment of a NECA in 2021. We assume that half of the fleet will have implemented each regulation after 10 years and will have completely implemented regulations after 30 years. This yields power curves with an exponent of 1.7 as long as there are not more than three concurrent fleets. Further, we assume that TIER I was completely implemented in 2012 and that the implementation for TIER I will be replaced by TIER II until 2021, when TIER III takes over. Hence, in the period 2021-2031 when all TIER fleets will be present, the TIER II fleet will remain constant at 50\% until 2031 when TIER III will reach $50 \%$. After that, TIER II is the only remainder in the TIER III fleet and decreases accordingly. The estimated fleet parts are presented in Fig. 10a. The ship emissions of $\mathrm{NO}_{x}$ in the Baltic Sea are then scaled, using fleetweighted factors, with $85 \%$ for TIER II and $20 \%$ for TIER III, relative to TIER I (J15). The resulting factors are shown in Fig. 10b. The deposition from shipping is then assumed to follow the trends of emissions in the NECA in the basins, shown in Figs. 8 and 9 (blue line). The deposition for OXN in 
Table 4. Emissions from shipping in the Baltic Sea $\left(\mathrm{Gg} \mathrm{yr}^{-1}\right)$.

\begin{tabular}{|c|c|c|c|c|c|c|c|c|}
\hline & \multicolumn{4}{|c|}{$\mathrm{SO}_{2}$} & \multicolumn{4}{|c|}{$\mathrm{NO}_{2}$} \\
\hline & \multicolumn{2}{|c|}{ BS } & \multicolumn{2}{|c|}{ NS } & \multicolumn{2}{|c|}{$\mathrm{BS}$} & \multicolumn{2}{|c|}{ NS } \\
\hline & $\begin{array}{l}\text { This } \\
\text { study }\end{array}$ & $\mathrm{J} 15$ & $\begin{array}{l}\text { This } \\
\text { study }\end{array}$ & $\mathrm{J} 15$ & $\begin{array}{l}\text { This } \\
\text { study }\end{array}$ & $\mathrm{J} 15$ & $\begin{array}{l}\text { This } \\
\text { study }\end{array}$ & $\mathrm{J} 15$ \\
\hline 2011 rv.4.4 and rv.4.8 & 89 & 80 & 201 & 155 & 304 & 337 & 678 & 662 \\
\hline 2012 & 73 & - & 165 & - & 313 & - & 700 & - \\
\hline 2013 & 62 & - & 140 & - & 247 & - & 555 & - \\
\hline 2030 scenario 3, w/o TIER II-III & c. 15 & 8 & 34 & 21 & 492 & 293 & 1097 & 642 \\
\hline 2030 scenario 3, w/TIER II-III & c. 15 & 8 & 34 & 21 & 264 & 217 & 589 & 457 \\
\hline
\end{tabular}
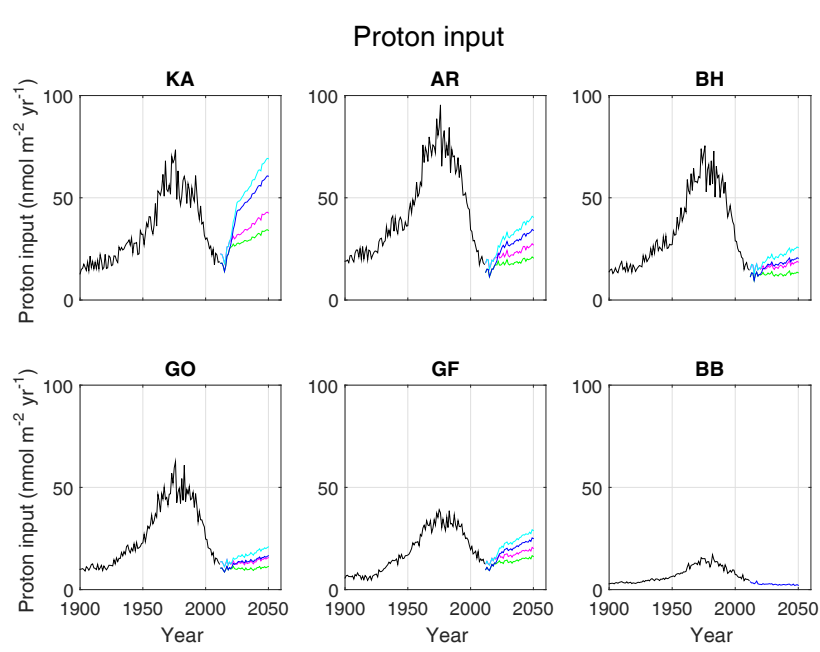

Figure 11. Annual proton input from OXS and OXN in six basins of the Baltic Sea (defined in Fig. 2) for the years 2010 to 2050. The red line corresponds with shipping scenario 3 and the magenta and cyan lines correspond with shipping scenarios 4 and 5, respectively (scrubber + atmospheric deposition). The black line shows historical shipping (derived in Omstedt et al., 2015). The green and blue lines show the implementation of TIER II and a NECA and scrubber scenarios 4 and 5, respectively.

the whole Baltic Sea with the effect from a NECA and TIER II is presented in Table 3. The ship contribution to the total will first increase for the atmospheric deposition, from $35 \%$ in 2011 to $45 \%$ in 2030, and then decrease to $34 \%$ in 2050 . In 2050 the atmospheric deposition will have been reduced from 77 to $37 \mathrm{Gg} \mathrm{yr}^{-1}$.

The deposition of OXS and OXN together acts as a strong acid in the water. The result is an acidifying effect and a $\mathrm{pH}$ decrease (Fig. 11). At $\mathrm{pH} 8$, a proton input of $1 \mathrm{nmol} \mathrm{m}^{-2}$ corresponds to a decrease in $\mathrm{pH}$ of $4 \times 10^{-6}$ for a mixed ocean surface layer of $10 \mathrm{~m}$. For $\mathrm{pH} 8.2$, this number is $7 \times 10^{-6}$. The largest effect is seen in the Kattegat, where ship traffic is high. In the worst-case scenario, even with a NECA, proton input is as high in 2050 as in 1970 to 1990. In the larger basins in the Baltic Sea proper, e.g. Eastern Gotland

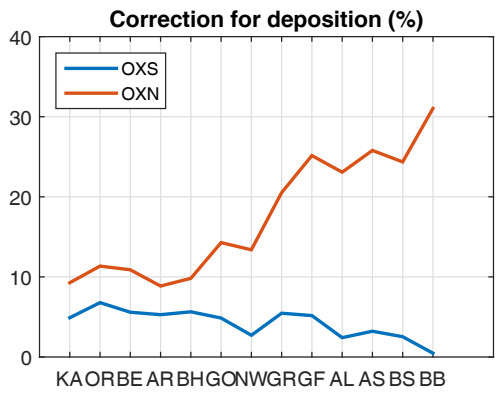

Figure 12. Correction of deposition caused by ship traffic in the different Baltic Sea basins.

Basin and Bornholm Basin, the effect is smaller, whereas in the Gulf of Finland the proton input is almost as high as in 1970 to 1990. It is concluded that the introduction of a NECA really lowers the nitrogen input into the Baltic Sea and the acidification is limited. However, using scrubbers, the effect is limited to a few percent in proton input.

The difference in physics in EMEP model rv.4.4 and 4.8 causes different deposition. With the assumption that rv.4.8 better represents the reality, a correction was calculated for the Baltic Sea basins. The result is shown in Fig. 12 for OXS and OXN. It is seen that for OXS the difference is below $5 \%$, with a decreasing trend counting from the Kattegat to the Bothnian Bay. The pattern for OXN is almost the opposite, with the largest correction in the northern parts. Also, the correction is higher, 10 to $30 \%$. The impact on the future scenarios is discussed in the next section. Due to the limited correction for sulfur deposition and the low values in comparison to scrubber exhaust, we neglect this correction. The nitrogen is more important, although the largest relative effect of the correction is in the Bothnian Bay, where the deposition is smallest, just $50 \mathrm{mg} \mathrm{m}^{2}$ in 2050 . Therefore, and since the scenarios are connected to other uncertainties, a correction was not made. 


\subsection{Present emissions and surface concentrations}

The spatial distribution of the emission from international shipping in the Baltic and North seas in 2011 (from the EMEP model) is demonstrated in Fig. 3a. The emission distribution (relative) is almost the same in 2013. The highest emission levels of the pollutant are found near big ports and shipping lanes, especially in the area around the English Channel and Denmark. Compared to ship emissions in 2011, there is a decrease in the inventory used for the EMEP model (Table 4). There has been a decrease, although not stepwise, as if all ships were using $1 \%$ sulfur in fuel, directly. This may be an effect of the interpolation as mentioned in Sect. 2.3 (Fagerli et al., 2015), i.e. an underestimation of the real ship emissions in 2012 and 2013. In Table 4 the emissions used in J15 are also shown. There are sometimes large differences, which are possibly an effect of the resolution of data and Baltic Sea basin areas. The largest deviation is for the North Sea, but this area is not directly analysed in the present investigation.

The evaluation of the EMEP model concentrations (with rv.4.8) in 2013 is summarized in Figs. A1 and A2 and Table A1 in the Appendix. The yearly averages of the measured and modelled concentrations of the pollutants were rather consistent (Table A1). The EMEP model underestimates the concentrations of $\mathrm{NO}_{x}, \mathrm{SO}_{2}$, and $\mathrm{PM}$ at both Utö and Vavihill, except for $\mathrm{NO}_{x}$ at Vavihill. The underestimations may be an effect of the underestimated emissions mentioned above (Fagerli et al., 2015). The model has some difficulty modelling the maximum values of the observed data (Fig. A1), which is possibly an effect of the resolution.

The seasonal variability in modelled and measured concentrations at Vavihill and Utö in 2013 is shown as monthly averages in Fig. A2. There is overall good agreement for most of the pollutants. However, $\mathrm{NO}_{2}$ and $\mathrm{SO}_{2}$ at Utö deviated significantly for some time periods and $\mathrm{PM}_{10}$ at Vavihill (Fig. A2g). The seasonal changes are well captured, but the variability is rather underestimated by the model. Bias, mentioned above, is also evident here. An aspect of the evaluation is that observed data from point measurements were compared to modelled data from gridded boxes with the size of $50 \mathrm{~km} \times 50 \mathrm{~km}$. The regional resolution of the model results in loss of variations in the grid box, and an average for the entire grid box is calculated, which in this study may have resulted in an underestimation of the maximum values in shipping lanes and ports. This may also be a reason why the model, in general, had some difficulty modelling the maximum values.

WHO guidelines for the annual average exposure for $\mathrm{PM}_{2.5}=10 \mu \mathrm{g} \mathrm{m}^{-3}, \mathrm{PM}_{10}=20 \mu \mathrm{g} \mathrm{m}^{-3}, \mathrm{NO}_{2}=40 \mu \mathrm{g} \mathrm{m}^{-3}$, and $\mathrm{SO}_{2}=20 \mu \mathrm{g} \mathrm{m}^{-3}$ (World Health Organization, 2006). EMEP model calculations by J15 have shown that in 2010 the WHO guidelines of the annual averages for $\mathrm{PM}_{10}$ and $\mathrm{PM}_{2.5}$ were exceeded in parts of the EMEP area. In the present calculations for the year 2013 the concentrations of PM still exceed the WHO guidelines in some restricted parts
PM2.5 rv4.4

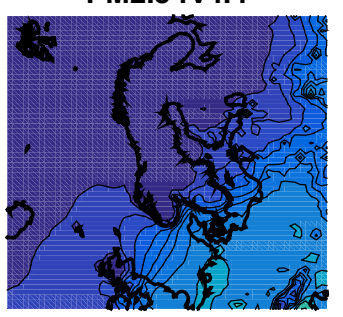

PM10 rv4.4

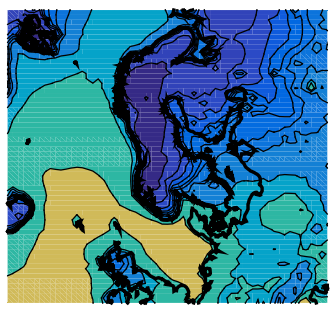

PM10 rv4.8

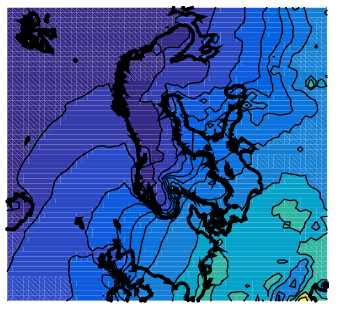

$\mu \mathrm{g} \mathrm{m}^{-3}$

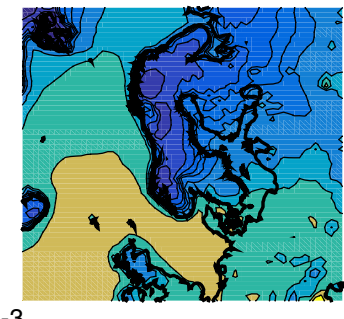

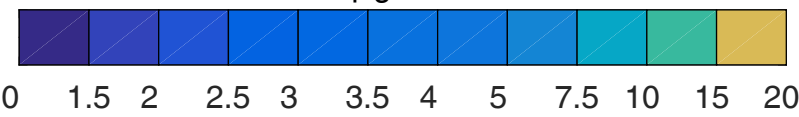

Figure 13. Annual mean concentration in 2011 of near-surface concentration (at $3 \mathrm{~m}$ level) of particulate matter from all emission sources in the EMEP area.

of the Baltic Sea area (Fig. 13). Surface concentrations (nearsurface concentrations at $3 \mathrm{~m}$ ) of $\mathrm{SO}_{2}$ and $\mathrm{NO}_{2}$ do not exceed WHO guidelines in 2011 to 2013 according to our EMEP calculations. It is also seen that concentrations decreased between 2011 and 2013 as an effect of less ship emissions in the EMEP model input. The $\mathrm{PM}_{2.5}$ concentration is in line with $\mathrm{J}_{15}$ but $\mathrm{PM}_{10}$ is much higher over the North Sea in the present study, probably because of a different definition of the content. This explanation cannot be referred to sea salt, which is 1 order of magnitude smaller.

International shipping in the Baltic Sea and the North Sea contributed significantly to total surface concentration of nitrogen oxides, sulfur dioxide, and PM from 2009 to 2013. In some areas in the Baltic Sea region, the contribution of nitric oxide, nitrogen dioxide, and sulfur dioxide from international shipping represents up to $80 \%$ of the total concentration of the pollutants from all emission sources in 2013. For $\mathrm{PM}_{2.5}$, the contribution from shipping to the total concentration was a maximum of around $20 \%$ and for $\mathrm{PM}_{10}$ it was $13 \%$. The highest concentrations of the pollutants are found near big ports and shipping lanes, where the shipping activities were most intense (Fig. 14). The highest concentrations of nitric oxide, nitrogen dioxide, and sulfur dioxide are more clearly along the shipping lanes, compared to $\mathrm{PM}_{2.5}$ and $\mathrm{PM}_{10}$, in agreement with Van Aardenne et al. (2013). Variations in the results between 2011 and 2013 are due to weather pattern and the decrease in ship emissions. Hence, locally the dif- 

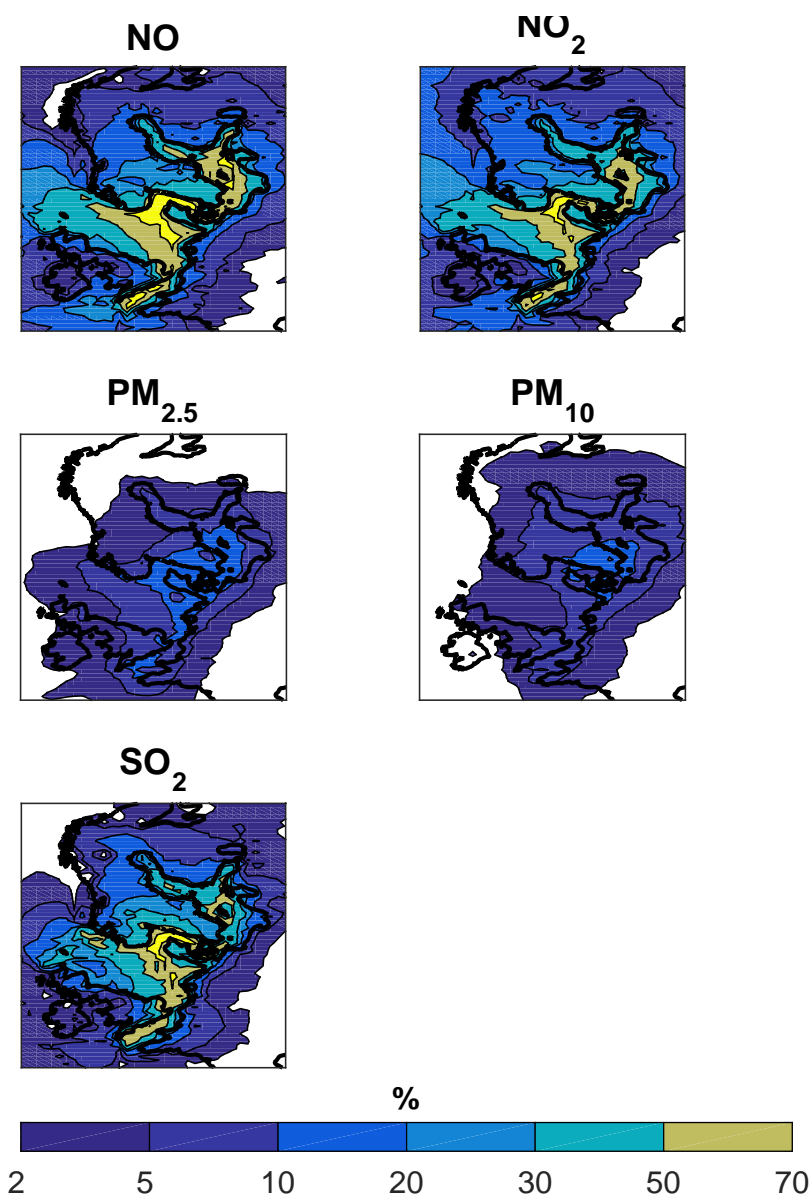

Figure 14. Percentage (\%) of the total surface concentration, caused by international shipping in the Baltic Sea and the North Sea in 2011.

ference between 2013 and 2011 can be up to 10 percentage units, both up and down, but less for PM, on the order of 2 percentage units. The actual annual mean concentration of $\mathrm{PM}_{2.5}$ from shipping is shown in Fig. 15. Comparing to J15, the values and spatial distribution are good overall. However, there is a tendency of smearing out, which is expected from the lower resolution in our study.

\subsection{Present deposition}

The simulated (by EMEP rv.4.8) wet deposition, in 2013, from shipping in the Baltic Sea and North Sea reaches over $60 \mathrm{mg}(\mathrm{S}) \mathrm{m}^{-2}$ and $80 \mathrm{mg}(\mathrm{N}) \mathrm{m}^{-2}$ in some of the areas in Europe (Figs. 3d and 16). The amount of wet deposition of the pollutants is high in coastal areas, which may be due to enhanced precipitation from coastal, orographic, and frictional effects on the meteorology. This results in more deposited pollutants in countries with a long coastline. This is consistent with the study of J15 in which it was found that the deposition of nitrogen from shipping was high in the seas and at coastlines. The large areas of OXN deposition over south-

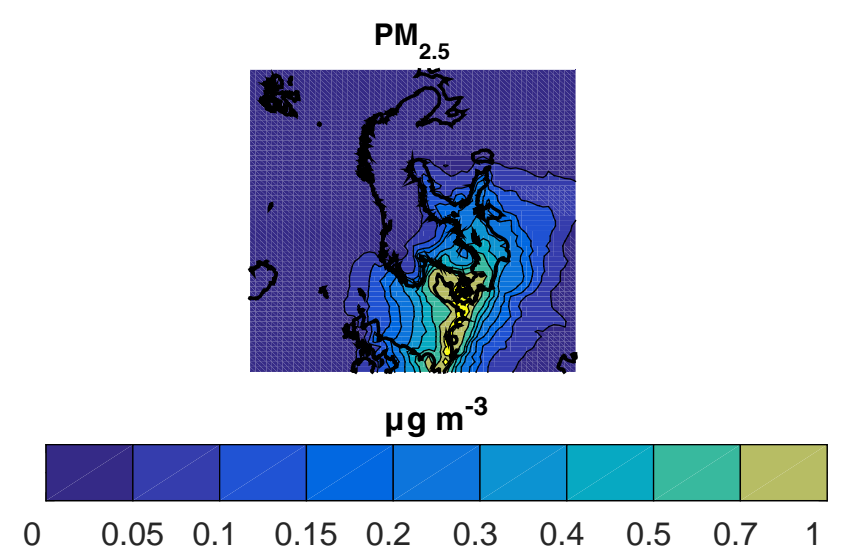

Figure 15. Concentration of $\mathrm{PM}_{2.5}$ caused by shipping.

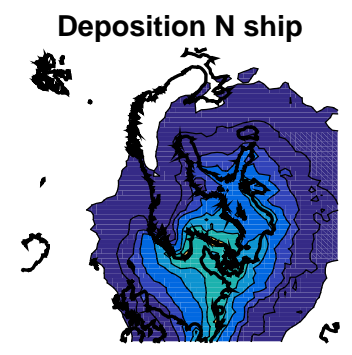

$\mathrm{mg} \mathrm{m}^{-2}$

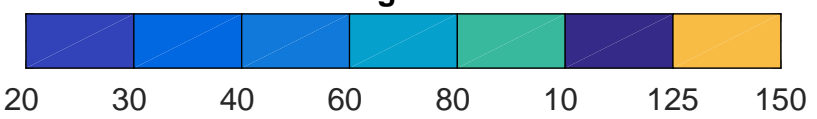

Figure 16. Deposition of OXN caused by shipping.

ern Norway, the west coast of Sweden, and west of Norway are seen both here and in J15. The dry deposition for the same year reaches a maximum of over $200 \mathrm{mg}(\mathrm{S}) \mathrm{m}^{-2}$ and $65 \mathrm{mg}(\mathrm{N}) \mathrm{m}^{-2}$. The highest cumulative wet and dry depositions are found in areas close to some of the shorelines in Europe and near big ports and shipping lanes (see Fig. 3). The total (wet and dry) cumulative deposition of OXS reached high values along the shipping lanes and its maximum values are found in areas around the inlet to the English Channel. The maximum values of the total (wet and dry) cumulative deposition of OXN are found at the Swedish west coast. Numbers and patterns of the $\mathrm{N}$ deposition are in line with J15. This indicates that the resolution higher than $50 \mathrm{~km} \times 50 \mathrm{~km}$ is not of major importance for deposition on the basin scale. Variations in the results between 2011 and 2013 are due to weather pattern and the decrease in ship emissions. Hence, locally the difference between 2013 and 2011 could be up to 10 percentage units, both higher and lower.

International shipping in the Baltic Sea and North Sea contributed significantly to the deposition of OXS and OXN from 2009 to 2013. In 2013, the percentage contribution from 
Dry OXS

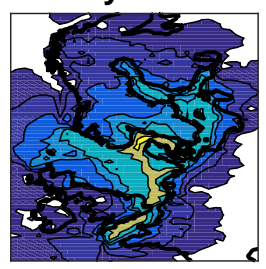

Wet OXS

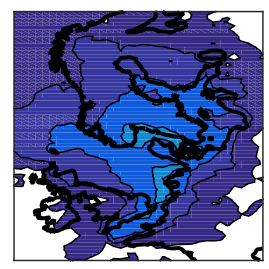

2

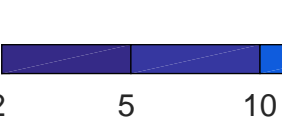

10
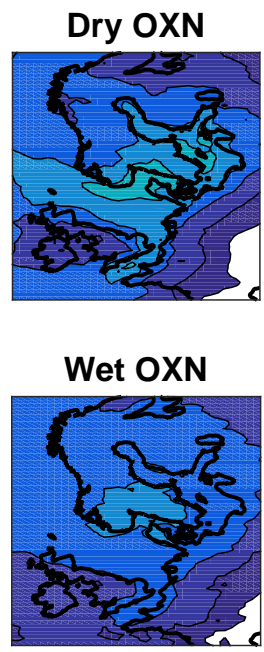

$\%$

20
30

50 here reduced $\mathrm{NO}_{x}$ emissions from the ship traffic are also evaluated. Here we included estimations of the effect from TIER II and a NECA from 2030. The conclusion that scrubbers increase the ocean acidification is still true, but it is decreased by less than $20 \%$ when including the effect from a NECA. Without scrubbers, the impact from a NECA on reducing acidification is very large. In other words, scrubbers offset the benefits of a NECA. The introduction of a limit of $0.5 \%$ sulfur in fuel outside SECA is estimated to have a minor effect on the Baltic Sea deposition since the atmospheric deposition is as low already now. The acid deposition from the scrubbers will also locally probably be, even if it is horizontally mixed, a magnitude or more larger than the basin averages. In the worst-case scenario, on the basin scale, and assuming a mean mixing depth of $10 \mathrm{~m}$ of the surface water, the $\mathrm{pH}$ decrease in the Kattegat can be on the order of $3 \times 10^{-4}$ per year (at $\mathrm{pH} 8.1$ ). Locally, along shipping lanes, the $\mathrm{pH}$ decrease can be comparable to $\mathrm{CO}_{2}$ uptake (Fig. 12a).

This modelling study was based on international shipping emissions, which means that the contribution of emissions from all shipping, including national, in the Baltic Sea and North Sea is somewhat higher than these results show. In further work it would be of interest to include national emissions. To obtain more robust results and to reduce uncertainties in the model, national reported input data should be put under more control and a future study should also examine how much impact it has on the results that several countries do not give complete reports of their annual emissions.

In this investigation we used a mixture of modelling and statistics, with all their uncertainties. We used constant meteorology in the future scenario, but limited the uncertainties by using the average of three meteorological years (20092011). However, in order to obtain more robust results, a study over a longer period of time is required, using the best case meteorology for every year. The resolution of the model, $50 \mathrm{~km} \times 50 \mathrm{~km}$, compared to that in J15, $14 \mathrm{~km} \times 14 \mathrm{~km}$, was shown to have a minor effect on basin-scale studies. However, to see local effects at the coast, finer resolution is needed. The validation to observations of coastal concentrations showed that the model performed well, given the rather low resolution.

The new regulation of permitted weight percentage of sulfur in marine fuel was introduced in January 2015, which makes it of interest to include 2015 and the following years in further studies to analyse the outcome of the new regulation. The $20150.1 \%$ limit was implemented in the scenarios but the compliance and the traffic scenarios on the longer timescale remain to be validated. In further studies, it would also be of interest to include a validation study of the deposition of the pollutants. Scenarios are based on assumptions on shipping activities as well as fuel use and cleaning patterns. Alternative fuel or cleaning techniques might be developed, giving alternative scenarios.

To identify the dispersion of the different components of PM from shipping, it would be of interest to model each 
component separately. Stricter regulations of sulfur content in maritime fuel and increased use of other fuels will result in a new mixture of PM from shipping. This ongoing change of composition of the pollutants makes it of interest to understand the dispersion of each separate component. In further studies a better resolution of the model is recommended to be used to examine the impact on a local level. No seasonal variations have been taken into account in this study. Results of the study of $\mathrm{J} 15$ demonstrate that emissions from international shipping vary to some extent over the year. The seasonal cycle of acidifying deposition is of importance for the surface water due to the biological cycle and stratification of the water, as seen in Omstedt et al. (2015).

\section{Summary and conclusions}

Model calculations using the chemical transport model EMEP show that the shipping in the Baltic Sea and North Sea is an important source of high near-surface concentrations of nitric oxide, nitrogen dioxide, sulfur dioxide, and particulate matter and deposition of OXN and OXS in the Baltic Sea and North Sea area. The highest concentrations of the pollutants were found near big ports and along shipping lanes. There, the international shipping in the Baltic Sea and North Sea was responsible for up to $80 \%$ of near-surface concentrations of nitric oxide, nitrogen dioxide, and sulfur dioxide in 2013. For $\mathrm{PM}_{2.5}$, the contribution from shipping to total concentration was up to $20 \%$ and for $\mathrm{PM}_{10}$ it was up to $13 \%$. It can also be seen that the contribution from shipping is also of importance over larger areas at sea and over land where many people are exposed. The percentage contribution from international shipping to dry deposition of sulfur was calculated to a maximum of $84 \%$ and contributions of dry deposition of nitrogen reached a maximum of $47 \%$ in 2013 . Wet deposition from shipping was spread over a larger area than dry deposition. Dry deposition of the pollutants caused by shipping represented a higher percentage of total amounts of the deposition than the wet deposition.

Future scenarios of ship emissions and the use of openloop scrubbers were combined with modelled deposition from ships and other sources, forming scenarios of acid deposition in the Baltic Sea basins. The impact of the different scenarios differs slightly for the different basins in the Baltic Sea, with the highest acidification in the southern basins. The scrubbers focus the sulfur along the shipping lanes. The ship part of acidifying ocean deposition increases for sulfur when including the scrubber water and for nitrogen oxides due to increasing ship traffic. Direct acidification of ocean deposition from shipping increases for sulfur when including openloop scrubbers. The impact is even larger for the Baltic Sea as a whole since almost all sulfur goes into the water and not to the surrounding land areas. The estimates of the reduction in OXN deposition from introducing a NECA in 2021 showed that there may be a large reduction of acidification. However, in relation to the worst-case scenario with $100 \%$ scrubbers in 2050 , this effect is minor.

Considering the negative effects of the air pollutants studied and as the pollutants are a contributing factor of several current challenges in the Baltic Sea and North Sea area, this study shows that continued analysis of the maritime sector is required in order to achieve sustainable shipping in the Baltic Sea and North Sea. For the marine environment, the large-scale usage of open-loop scrubbers should be avoided, at least with the use of residual oil.

To conclude,

- open-loop scrubbers concentrate sulfur input along shipping lines, with enhanced potential for acidification, even if the atmospheric deposition is estimated to be low;

- acidification from a fleet with $100 \%$ scrubbers, using high-sulfur-content fuel, may reach the total deposition levels along the shipping lanes from the 1970s to 1990s;

- open-loop scrubbers will contribute significantly to the marine environment, unless medium-sulfur-content distillates are used.

Data availability. Deposition data used and produced in this work are available at Environment Climate Data Sweden (ECDS). The historical data are found in Claremar and Rutgersson (2017b) at https://doi.org/10.5879/ECDS/2017-10-10.2/1. The scenario deposition data produced are found in Claremar and Rutgersson (2017a) at https://doi.org/10.5879/ECDS/2017-10-10.1/1. 
Appendix A: Concentration validation at Vavihill and Utö

Table A1. Comparison of model daily concentration average results from the EMEP model and measured data for 2013 at Utö and Vavihill. Obs: observed data; Mod: modelled data; Corr: correlation coefficient; and RMSE: root mean square error.

\begin{tabular}{llrcrcc}
\hline Station & Component & $\begin{array}{r}\text { Obs. } \\
\left(\mu \mathrm{g} \mathrm{m}^{-3}\right)\end{array}$ & $\begin{array}{c}\text { Mod. } \\
\left(\mu \mathrm{g} \mathrm{m}^{-3}\right)\end{array}$ & $\begin{array}{r}\text { Bias } \\
(\%)\end{array}$ & $\begin{array}{r}\text { Corr. } \\
(r)\end{array}$ & RMSE \\
\hline Vavihill & $\mathrm{NO}_{2}$ & 3.69 & 5.05 & 36.7 & 0.72 & 3.03 \\
& $\mathrm{SO}_{2}$ & 0.42 & 0.38 & -8.2 & 0.70 & 0.35 \\
& $\mathrm{PM}_{2.5}$ & 5.89 & 4.71 & -20.0 & 0.66 & 3.76 \\
& $\mathrm{PM}_{10}$ & 13.02 & 8.90 & -30.9 & 0.49 & 7.48 \\
Utö & $\mathrm{NO}_{2}$ & 3.25 & 2.32 & -28.7 & 0.51 & 1.95 \\
& $\mathrm{SO}_{2}$ & 0.58 & 0.26 & -54.5 & 0.48 & 0.49 \\
& $\mathrm{PM}_{2.5}$ & 3.93 & 3.23 & -18.0 & 0.54 & 3.02 \\
\hline
\end{tabular}
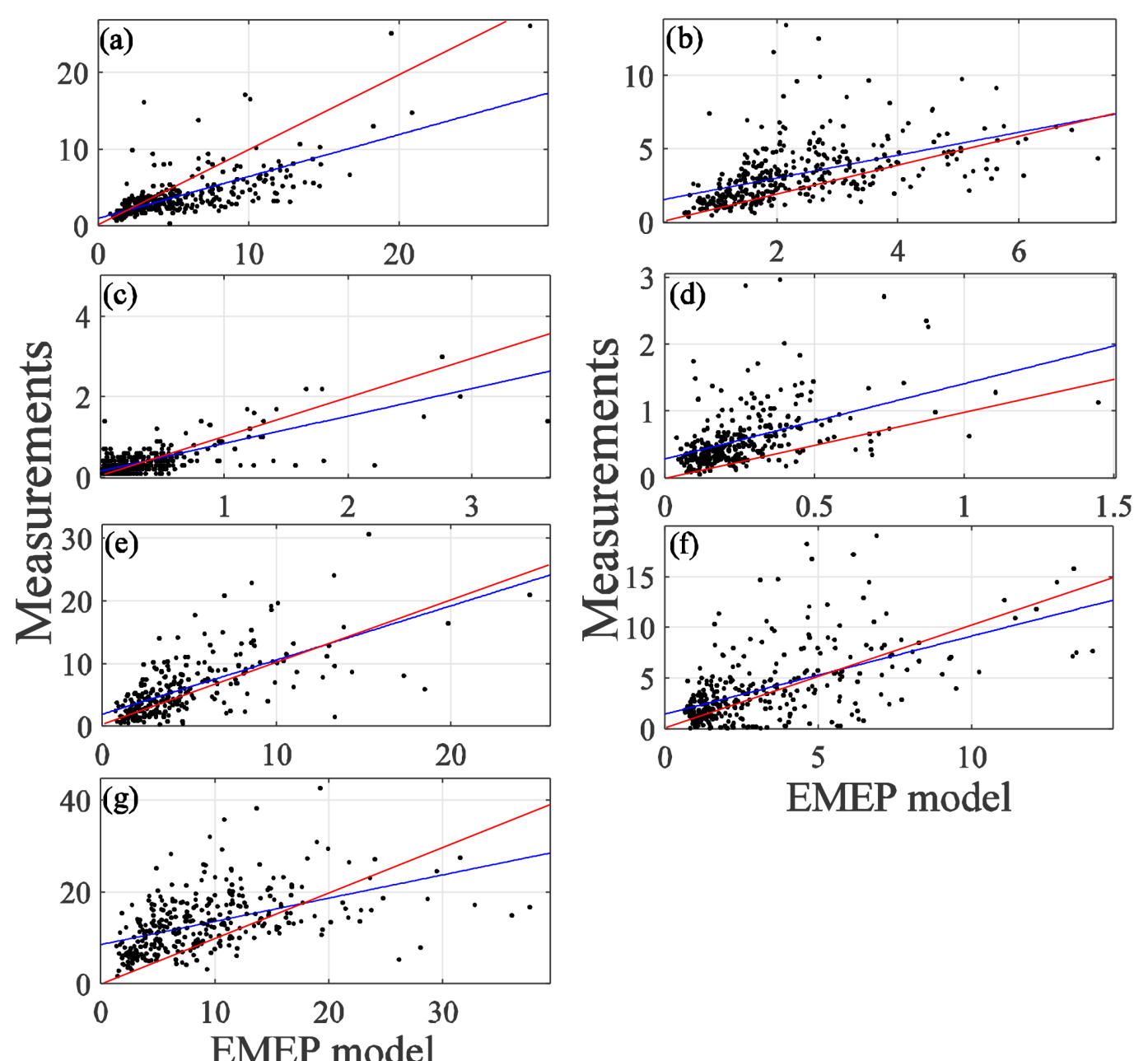

Figure A1. Scatter plots of model results vs. measured data of daily average concentrations of $\mathrm{SO}_{2}, \mathrm{NO}_{2}$, and particulate matter at Vavihill (a, c, e, g) and Utö $(\mathbf{b}, \mathbf{d}, \mathbf{f})$ in the year $2013\left(\mu \mathrm{g} \mathrm{m}^{-3}\right)$. The red line corresponds to a $1: 1$ ratio, and the blue line shows the linear relationship between measured and modelled concentrations. 

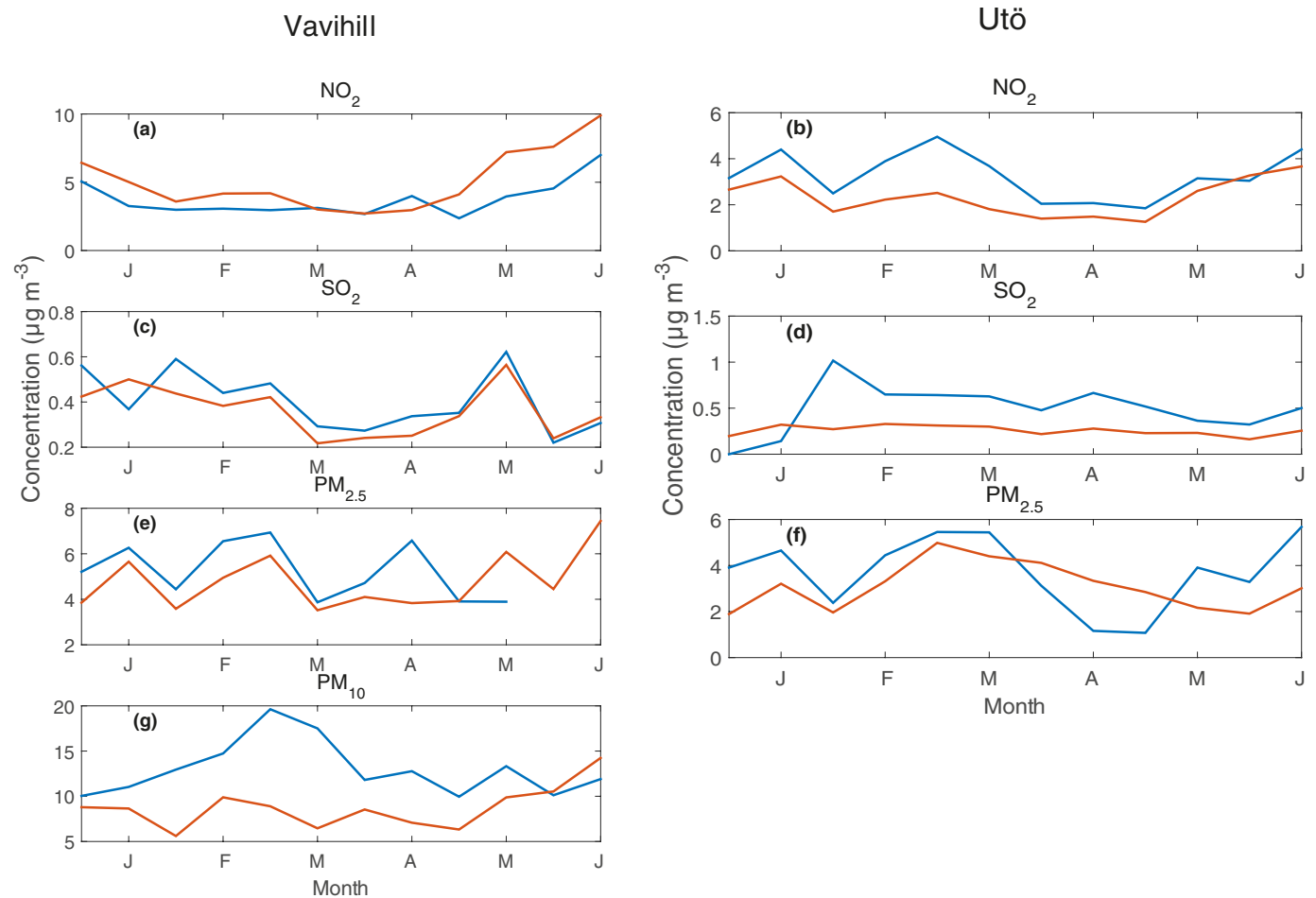

Figure A2. Measured and modelled monthly average of concentrations of the pollutants at Vavihill and Utö in 2013. The red line corresponded to concentrations of the EMEP modelling and the blue line showed measured concentrations. 
Competing interests. The authors declare that they have no conflict of interest.

Special issue statement. This article is part of the special issue "Multiple drivers for Earth system changes in the Baltic Sea region". It is a result of the 1st Baltic Earth Conference, Nida, Lithuania, 13-17 June 2016.

Acknowledgements. This work is part of the Swedish Research Council Formas programme "Commercial shipping as a source of acidification in the Baltic Sea (SHIpH)", contract no. 2012-2120. The SHIpH group is acknowledged for valuable discussion concerning the traffic and scrubber scenarios, as well as scenario definitions. It is also part of the "Baltic Earth - Earth System Sciences for the Baltic Sea Region” programme. Magnuz Engardt at SMHI is thanked for the MATCH model deposition output. EMEP/MSC-W is acknowledged for the EMEP model code and input data. The EMEP model computations were performed using resources provided by SNIC via the Uppsala Multidisciplinary Center for Advanced Computational Science (UPPMAX) under projects snic2014-1-75 and snic2015-6-139.

Edited by: Marcus Reckermann

Reviewed by: two anonymous referees

\section{References}

Amann, M., Borken, J., Böttcher, H., Cofala, J., Hettelingh, J., Heyes, C., Holland, M., Hunt, A., Klimont, Z., Mantzos, L., Ntziachristos, L., Obersteiner, M., Posch, M., Schneider, U., Schöpp, W., Slootweg, J., Witzke, P., Wagner, A., and Winiwarter, W.: Greenhouse Gases and Air Pollutants in the European Union: Baseline Projections up to 2030, Ec4macs Interim Assessment, IIASA, available at: http://webarchive.iiasa.ac.at/rains/ reports/EC4MACS_IR_11.pdf (last access: 11 August 2014), 2011.

Andersen, J. H., Korpinen, S., Laamanen, M., Wolpers, U., Claussen, U., Durkin, M., Hasselström, L., Ljungberg, R., Meski, L., Murray, C., Reker, J., Soutukorva, À., Stankiewicz, M., and Zweifel, U. L.: Ecosystem Health of the Baltic Sea, HELCOM Initial Holistic Assessment No. 122, Baltic Sea Environment Proceedings, 1-68, http://www.helcom.fi/Lists/Publications/BSEP122.pdf (last access: October 2017), 2010.

Andersson, P., Håkansson, B., Håkansson, J., and Sahlsten, E.: Marine Acidification on Effects and Monitoring of Marine Acidification in the Seas Surrounding Sweden, SMHI Report No. 92, SMHI, Gothenburg, Sweden, 1-62, 2008.

Claremar, B. and Rutgersson, A.: Deposition scenarios from Baltic Sea ship traffic with scrubbers, (Version 1) [Data set], Environment Climate Data Sweden (ECDS), https://doi.org/10.5879/ ECDS/2017-10-10.1/1, 2017a.

Claremar, B. and Rutgersson, A.: 20th century deposition from Baltic Sea ship traffic, (Version 1) [Data set], Environment Climate Data Sweden (ECDS), https://doi.org/10.5879/ECDS/ 2017-10-10.2/1, 2017b.
Claremar, B., Wällstedt T., Rutgersson, A., and Omstedt, A.: Deposition of acidifying and neutralising compounds over the Baltic Sea drainage basin between 1960 and 2006, Boreal Environ. Res., 18, 425-445, 2013.

CleanShip: Cleanship, Clean Baltic Sea Shipping, available at http://www.clean-baltic-sea-shipping.com/uploads/files/ CLEANSHIP_final_report_for_download.pdf (last access: 28 October 2015), 2013.

Cofala, J., Amann, M., Hayes, C., Wagner, F., Klimont, Z., Posch, M., Schöpp, W., Tarrasón, L., Jonson, J. E., Whall, C., and Stavrakaki, A.: Analysis of policy measures to reduce ship emissions in the context of the revision of national emission ceilings directive,Institute for Applied Systems Analysis (IIASA), Austria, 6-107, 2007.

Corbett, J. J. and Fischbeck, P.: Emissions from ships, Science, 11, 823-824, 1997.

Corbett, J. J., Winebrake, J. J., Green, E. H., Kasibhatla, P., Eyring, V., and Lauer, A.: Mortality from ship emissions: a global assessment, Environ. Sci. Technol., 41, 8512-8518, 2007.

De Ceuster, G., va Herbruggen, B., and Logghe, S.: TREMOVE description of model and baseline version 2.41. Report for the European Commission, DG ENV, Chapter VI - The maritime model, Rep. B4-3040/2002/342069/MAR/C.1., European Commision, Brussels, Belgium, 2006.

Doney, S. C., Mahowald, N., Lima, I., Feely, R. A., Mackenzie, F. T., Lamarque, J. F., and Rasch, P. J.: Impact of anthropogenic atmospheric nitrogen and sulfur deposition on ocean acidification and the inorganic carbon system, P. Natl. Acad. Sci. USA, 104, 14580-14585, https://doi.org/10.1073/pnas.0702218104, 2007.

Engardt, M. and Langner, J.: Simulations of future sulfur and nitrogen deposition over Europe using meteorological data from three regional climate projections, Tellus B, 65, 20348, https://doi.org/10.3402/tellusb.v65i0.20348, 2013.

ENTEC: Quantification of Emissions From Ships Associated With Ship Movements Between Ports in the European Community, A Report for the European Commission, Entec UK Limited, Northwich, UK, 1-21, 2002.

ENTEC: Service Contract on Ship Emissions: Assignment, Abatement and Marked-Based Instruments, Task 1 - Preliminary Assignment of Ship Emissions to European Countries, Rep., London, 1-171, 2005.

ENTEC: Defra, UK Ship Emissions Inventory, Final Report, Crown Copyright, 1-168, available at: http://uk-air.defra.gov.uk/reports/ cat15/1012131459_21897_Final_Report_291110.pdf (last access: 6 October 2017), 2010.

Eyring, V., Köhler, H. W., van Aardenne, J., and Lauer, A.: Emissions from international shipping: 1. The last 50 years, J. Geophys. Res., 110, D17305, https://doi.org/10.1029/2004JD005619, 2005.

Eyring, V., Isaksen, I., Berntsen, T., Collins, W., Corbett, J., Endresen, Ø., Grainger, R., Moldanova, J., Schlager, H., and Stevenson, D.: Transport impacts on atmosphere and climate: shipping, Atmos. Environ., 44, 4735-4771, 2010.

Fagerli, H., Tsyro, S., Simpson, D., Schulz, M., Gauss, M., Jonson, J.-E-., Benedictow, A., Wind, P., Nyiri, A., Steensen, B. M., and Valiyaveetil, S.: EMEP/MSC-W Model Performance for Transboundary Particulate Matter, Photo-Oxidants, Acidifying and Eutrophying Components, EMEP Status Report 1/2015, 
Norweigian Meteorological Institute, Oslo, Norway, 1-228, 2015.

Finnish Meteorological Institute: Mittausasema Länsi-Turunmaa: Utö, available at: http://www.ilmanlaatu.fi/mittaaminen/verkot/ asemat/asemat.php?nws=1\&ss=349, last access: 12 October 2015 .

Fridell, E., Jernström, M., and Segersson, D.: Översyn av sjöfartens emissioner av luftföroreningar, Svenska Miljö Emissions Data, SMHI, Norrköping, Sweden, 1653-8108, 2008.

Fuglestvedt, J. and Berntsen, T.: Shipping emissions: from cooling to warming of climates and reducing impacts on health, Environ. Sci. Technol., 43, 9057-9062, 2009.

Gauss, M., Benedictow, A., Hjellbrekke, A.-G., Mareckova, K., Nyíri, A., and Wankmüller, R.: Status of transboundary pollution in 2011, in: Transboundary Acidification, Eutrophication and Ground Level Ozone in Europe in 2011, EMEP/MSC-W Status Report 1/2013, The Norwegian Meteorological Institute, Oslo, Norway, 1-205, 2013.

Gauss, M., Tsyro, S., Benedicrow, A. C., Hjellbrekke, A.-G., and Solberg, S.: EMEP/MSC-W Model Performance for Acidifying and Eutrophying Components, Photo-Oxidants and Particulate Matter in 2013, Supplementary Material to the EMEP Status Report 1/2015, The Norwegian Meteorological Institute, Oslo, Norway, 1-96, 2015.

Hassellöv, I.-M., Turner, D. R., Lauer, A., and Corbett, J. J.: Shipping contributes to ocean acidification, Geophys. Res. Lett., 40, 2731-2736, https://doi.org/10.1002/grl.50521, 2013.

Hunter, K. A., Liss, P. S., Surapipith, V., Dentener, F., Duce, R., Kanakidou, M., Kubilay, N., Mahowald, N., Okin, G., Sarin, M., Uematsu, M., and Zhu, T.: Impacts of anthropogenic $\mathrm{SO}_{x}, \mathrm{NO}_{x}$ and $\mathrm{NH}_{3}$ on acidification of coastal waters and shipping lanes, Geophys. Res. Lett., 38, L13602, https://doi.org/10.1029/2011g1047720, 2011.

IMO: Prevention of Air Pollution from Ships, Information on $\mathrm{NO}_{x}$ Emissions from Shipping in the Baltic Sea Area, available at: http://www.sjofartsverket.se/pages/14179/57-inf14.pdf (last access: 1 September 2017), 2007.

IMO: Guidelines for Monitoring the Worldwide Average Sulphur Content of Residual Fuel Oils Supplied for Use on Board Ships (MEPC59/24/Add.1), International Maritime Organization (IMO), London, UK, 2009.

IMO: IMO profile, IMO (International Maritime Organization), available at: https://business.un.org/en/entities/13 (last access: 6 October 2017), 2016.

IMO: Pollution Prevention, available at: http://www.imo.org/en/ OurWork/Environment/PollutionPrevention/Pages/Default.aspx, last access: 1 September 2017.

IVL - Swedish Environmental Research Institute: Information om Mätstation, available at: http://www3.ivl.se/db/plsql/dvst_meta_ statb1.QueryViewByKey?P_STAT_ID=106\&Z_CHK=39128 (last access: 14 January 2016), 2015.

Jalkanen, J.-P., Brink, A., Kalli, J., Pettersson, H., Kukkonen, J., and Stipa, T.: A modelling system for the exhaust emissions of marine traffic and its application in the Baltic Sea area, Atmos. Chem. Phys., 9, 9209-9223, https://doi.org/10.5194/acp-9-92092009, 2009.

Jalkanen, J.-P., Johansson, L., Kukkonen, J., Brink, A., Kalli, J., and Stipa, T.: Extension of an assessment model of ship traffic exhaust emissions for particulate matter and carbon monoxide, At- mos. Chem. Phys., 12, 2641-2659, https://doi.org/10.5194/acp12-2641-2012, 2012.

Jalkanen, J.-P., Johansson, L., and Kukkonen, J.: A comprehensive inventory of ship traffic exhaust emissions in the Baltic Sea from 2006 to 2009, Ambio, 43, 311-324, 2014.

Jonson, J.-E., Tarrason, L., Klein, H., Vestreng, V., Cofala, J., and Whall, C.: Effects of ship emissions on European groundlevel ozone in 2020, Int. J. Remote Sens., 30, 4099-4110, https://doi.org/10.1080/01431160902821858, 2009.

Jonson, J. E., Jalkanen, J. P., Johansson, L., Gauss, M., and Denier van der Gon, H. A. C.: Model calculations of the effects of present and future emissions of air pollutants from shipping in the Baltic Sea and the North Sea, Atmos. Chem. Phys., 15, 783798, https://doi.org/10.5194/acp-15-783-2015, 2015.

Lamarque, J.-F., Bond, T. C., Eyring, V., Granier, C., Heil, A., Klimont, Z., Lee, D., Liousse, C., Mieville, A., Owen, B., Schultz, M. G., Shindell, D., Smith, S. J., Stehfest, E., Van Aardenne, J., Cooper, O. R., Kainuma, M., Mahowald, N., McConnell, J. R., Naik, V., Riahi, K., and van Vuuren, D. P.: Historical (1850-2000) gridded anthropogenic and biomass burning emissions of reactive gases and aerosols: methodology and application, Atmos. Chem. Phys., 10, 7017-7039, https://doi.org/10.5194/acp-10-7017-2010, 2010.

Lloyd's register: International Maritime Organization Marine Exhaust Emissions, Quantification study, 98/EE/7036, Baltic Sea, London, 1998.

Matthias, V., Bewersdorff, I., Aulinger, A., and Quante, M.: The contribution of ship emissions to air pollution in the North Sea regions, Environ. Pollut., 158, 2241-2250, 2010.

Monks, P., Granier, C., Fuzzi, S., Stohl, A., Williams, M., Akimoto, H., Amann, M., Baklanov, A., Baltensperger, U., Bey, I., Blake, N., Blake, R., Carslaw, K., Cooper, O., Dentener, F., Fowler, D., Fragkou, E., Frost, G., Generoso, S., Ginoux, P., Grewe, V., Guenther, A., Hansson, H., Henne, S., Hjorth, J., Hofzumahaus, A., Huntrieser, H., Isaksen, I. S., Jenkin, M., Kaiser, J., Kanakidou, M., Klimont, Z., Kulmala, M., Laj, P., Lawrence, M., Lee, J., Liousse, C., Maione, M., McFiggans, G., Metzger, A., Mieville, A., Moussiopoulos, N., Orlando, J., O’Down, C., Palmer, P., Parrish, D., Petzold, A., Platt, U., Pöschl, U., Prévot, A. S., Reeves, C., Reimann, S., Rudich, Y., Sellegri, K., Steinbrecher, R., Simpson, D., ten Brink, H., Theloke, J., van der Werf, G., Vautard, R., Vestreng, V., Vlachokostas, C., and von Glasow, R.: Atmospheric composition change - global and regional air quality, Atmos. Environ., 43, 5268-5350, 2009.

Olivier, J. G. J., Bouwman, A. F., Maas, C. W. M., van der Berdowski, J. J. M., Veldt, C., Bloos, J. P. J., Visschedijk, A. J. H., Zandveld, P. Y. J., and Haverlag, J. L.: Description of EDGAR Version 2.0: A set of global emission inventories of greenhouse gases and ozone-depleting substances for all anthropogenic and most natural sources on a per country basis and on $1^{\circ} \times 1^{\circ}$ grid, RIVM Rapport 771060002, RIVM, Bilthoven, 1996.

Olivier, J. G. J., Janssens-Maenhout, G., Peters, J., and Wilson, J.: Long term trend in global $\mathrm{CO}_{2}$ emissions, JRC65918, PBL Netherlands Environmental Assessment Agency and European Commission Publications Office, The Hague, the Netherlands, http://www.pbl.nl/sites/default/files/cms/publicaties/ 
C02Mondiaal_webdef_19sept.pdf? (last access: October 2017), 2011.

Omstedt, A.: Guide to Process Based Modelling of Lakes and Coastal Seas, in: Springer-Praxis Books in Geophysical Sciences, 2nd Edn., Springer, Berlin, Heidelberg, https://doi.org/10.1007/978-3-319-17990-2, 2015.

Omstedt, A., Edman, M., Claremar, B., and Rutgersson, A.: Modelling the contributions to marine acidification from deposited $\mathrm{SO}_{x}, \mathrm{NO}_{x}$, and $\mathrm{NH}_{x}$ in the Baltic Sea: past and present situations, Cont. Shelf Res., 111, 234-249, https://doi.org/10.1016/j.csr.2015.08.024, 2015.

Orr, J.: Recent and future changes in ocean carbonate chemistry, in: Ocean Acidification, edited by: Gattuso, J.-P. and Hansson, L., OUP, Oxford, 41-66, 2011.

Rhein, M., Rintoul, S. R., Aoki, S., Campos, E., Chambers, D., Feely, R. A., Gulev, S., Johnson, G. C., Josey, S. A., Kostianoy, A., Mauritzen, C., Roemmich, D., Talley, L. D., and Wang, F.: Observations: Ocean, in: Climate Change 2013: The Physical Science Basis, Contribution of Working Group I to the Fifth Assessment Report of the Intergovernmental Panel on Climate Change, edited by: Stocker, T. F., Qin, D., Plattner, G.-K., Tignor, M., Allen, S. K., Boschung, J., Nauels, A., Xia, Y., Bex, V., and Midgley, P. M., Cambridge University Press, Cambridge, 255-315, 2013.

Robertson, L., Langner, J., and Engardt, M.: An Eulerian limitedarea atmospheric transport model, J. Appl. Meteorol., 38, 190210, 1999.

S\&P Global Platts: The IMO's 2020 Global Sulfur Cap: What a 2020 Sulfur-Constrained World Means for Shipping Lines, Refineries and Bunker Suppliers, Shipping Special Report, https://www.platts.com/IM. Platts.Content/InsightAnalysis/IndustrySolutionPapers/

SR-IMO-2020-Global-sulfur-cap-102016.pdf (last access: October 2017), October 2016.

Schulz, M., Gauss, M., Benedicrow, A. C., Eiof Jonson, J., Tsyro, S., Nyiri, A., and Simpson, D.: Transboundary Acidification, Eutrophication and Ground Level Ozone in Europe in 2011, EMEP Report 1/2013, 1-205, EMEP, Oslo, Norway, http://emep.int/publ/reports/2011/status_report_1_2011.pdf (last access: October 2017), 2011.

Seinfeld, J. H. and Pandis, S. N.: Atmospheric Chemistry and Physics: From Air Pollution to Climate Change, 2nd Edn., John Wiley \& Sons, Hoboken, New Jersey, USA, 2006.
Simpson, D., Benedictow, A., Berge, H., Bergström, R., Emberson, L. D., Fagerli, H., Flechard, C. R., Hayman, G. D., Gauss, M., Jonson, J. E., Jenkin, M. E., Nyíri, A., Richter, C., Semeena, V. S., Tsyro, S., Tuovinen, J.-P., Valdebenito, Á., and Wind, P.: The EMEP MSC-W chemical transport model - technical description, Atmos. Chem. Phys., 12, 7825-7865, https://doi.org/10.5194/acp-12-7825-2012, 2012.

Sjöberg, K. and Peterson, K.: Utredning avseende flytt av mätstationen Vavihill, No. U4824, IVL Svenska Miljöinstitutet, available at: http://www.diva-portal.org/smash/get/diva2: 748240/FULLTEXT01.pdf (last access: 14 January 2016), 2014.

Turner, D., Edman, M., Gallego-Urrea, J. A., Claremar, B., Hassellöv, I. M., Omstedt, A., and Rutgersson, A.: Potential future contribution of shipping to acidification of the Baltic Sea, https://doi.org/10.1007/s13280-017-0950-6, in press, 2017.

Van Aardenne, J. A.,Dentener, F. J., Olivier, J. G. J., Klein Goldewijk, C. G. M., and Lelieveld, J.: A $1^{\circ} \times 1^{\circ}$ resolution data set of historical anthropogenic trace gas emissions for the period 18901990, Global Biogeochem. Cy., 15, 909-928, 2001.

Van Aardenne, J., Colette, A., Degraeuwe, B., Hammingh, P., Viana, M., and Vlieger, I.: The impact of international shipping on European air quality and climate forcing, Technical Report No. 4/2013, EEA (European Environment Agency), Copenhagen, Denmark, 1-84, 2013.

Vestreng, V.: Review and Revision. Emission Data Reported to CLRTAP, EMEP MSC-W Status Report 2003, Technical Report Note 1/2003, Meteorological Synthesizing Centre - West, Norwegian Meteorological Institute, Oslo, Norway, 1-134, 2003.

Wang, C., Corbett, J., and Firestone, J.: Improving spatial representation of global ship emissions inventories, Environ. Sci. Technol., 42, 193-199, 2008.

WHO - World Health Organization: WHO Air Quality Guidelines for Particulate Matter, Ozone, Nitrogen Dioxide and Sulfur Dioxide, Global Update, Summary of Risk Assessment, available at: http://apps.who.int/iris/bitstream/10665/69477/1/ WHO_SDE_PHE_OEH_06.02_eng.pdf (last access: 10 November 2015), 2006.

Winnes, H., Moldanová, J., Anderson, M., and Fridell, E.: On-board measurements of particle emissions from marine engines using fuels with different sulfur content, J. Eng. Marit. Environ., 230, 45-54, https://doi.org/10.1177/1475090214530877, 2014. 